\title{
Conciencia política de las mujeres durante la independencia de Nueva Granada. El caso de Santafé entre 1810 y $1820^{*}$
}

\section{Women's Political Awareness during the Independence of Nueva Granada. The Case of Santafe between 1810 and 1820}

\author{
Ana Serrano Galvis \\ El Colegio de México, México \\ anaserranogalvis@gmail.com
}

Resumen: Este artículo se pregunta por el significado que tuvo para las mujeres el proceso de independencia de Nueva Granada, específicamente en la ciudad capital de Santafé entre 1810 y 1820. Para captarlo se vale del concepto de conciencia política, que entiende lo político más allá del apoyo explícito a una causa o bando políticos, permitiendo la inclusión de aquellas mujeres que no tomaron partido y simplemente se adaptaron a las circunstancias que les tocó vivir. Posteriormente, analiza la forma en que se manifestó la conciencia política de las mujeres en relación con el comportamiento correcto o incorrecto de las autoridades y a las propuestas de las distintas facciones políticas que disputaron el poder. Como hipótesis se propone que las mujeres, además de participar activamente en eventos y movimientos políticos, también participaron activamente de la cultura política de la época y contribuyeron a su constante redefinición.

* El presente trabajo profundiza un tema tratado en mi tesis de maestría en Estudios de Género de El Colegio de México (Serrano, 2012). 
Palabras clave: conciencia política; mujeres; independencia; Nueva Granada; género.

Abstract: This article explores the meaning for women of the independence of Nueva Granada, specifically in the capital of Santafé city between 1810 and 1820. To this end, it uses the concept of political awareness, which understands politics as going beyond explicit support for a political cause or group, which permits the inclusion of women who did not take sides and merely adapted to the circumstances in which they happened to live. It subsequently analyzes the way women's political awareness regarding the right or wrong behavior of the authorities and the proposals of the various political factions fighting over power was expressed. The hypothesis put forward is that women, in addition to actively participating in political events and movements, also played a key role in the political culture of the time and contributed to its constant redefinition.

Key words: political awareness; women; independence; Nueva Granada; gender.

Fecha de recepción: 27 de mayo de 2015 Fecha de aceptación: 11 de abril de 2016

\section{INTRODUCCIÓN}

T a historiografía actual sobre las mujeres en la independencia de Nueva $\perp$ Granada las ha visibilizado como actoras históricas y políticas activas y autónomas y ha revelado el papel fundamental que desempeñaron en las luchas y en todos los ámbitos de su sociedad (González, 2010; Lux, 2014; Muñoz, 2011; Ramírez, 2014). Sin embargo, ha enfatizado más en sus aportes a la emancipación que en el significado que esta pudo haber tenido para ellas. Este trabajo propone captar su comprensión del entorno político a partir del concepto de conciencia política, que aquí se define como la forma particular que dieron los actores colectivos o individuales a la cultura política en la que se hallaban inmersos, a través de los usos particulares que hicieron de los

\section{(이요 $(3$}


lenguajes y conceptos políticos a su disposición. Lenguajes entendidos a la manera de Palti (2007, pp. 17-56), no como un conjunto de ideas o conceptos, sino como un modo característico de producirlos que es flexible, parcial, indeterminado semánticamente y precaria e históricamente articulado. A diferencia de los conceptos y sistemas de pensamiento, los lenguajes no se muestran perfectamente consistentes, coherentes, racionales, lógicamente integrados, autocontenidos y ajenos a la dimensión temporal, sino que remiten a lo que el autor ha llamado principio de incompletitud constitutiva de los sistemas conceptuales. Esta aproximación permite abarcar críticamente aquellos discursos que desde otras perspectivas parecerían simples antagonismos, pero que bajo la de los lenguajes políticos da cuenta de la gran complejidad discursiva que tuvo lugar en ese periodo. No se trataría de reemplazar el concepto de cultura política por el de lenguajes políticos, sino recurrir a estos últimos como el medio a través del cual se construían los contenidos de la cultura política y no simplemente a través del cual estos se reflejaban. Los conceptos políticos se abordan a la manera de Javier Fernández (2009, pp. 25-34), quien apuesta a una historia de los conceptos políticos interesada en el utillaje conceptual de los agentes individuales y colectivos, con el fin de lograr una mejor comprensión de sus motivaciones y el sentido de su acción política. Su objetivo es rastrear los usos de un concepto en el tejido discursivo de la época, es decir, observar cómo los diversos agentes históricos se servían del mismo para construir sus argumentaciones y relatos de legitimación y deslegitimación.

Cultura, lenguajes y conceptos políticos actuarían a la manera en que William Roseberry (2002, pp. 213-226) define el concepto de hegemonía: como un marco discursivo común, necesario para que los distintos actores de la sociedad lograran entender en torno a qué puntos trataban de ponerse de acuerdo o disputar. Durante el periodo de independencia dicho marco no se referiría a una corriente política particular, sino al entorno político en toda su complejidad, es decir, al conjunto de discursos emanados de los diferentes proyectos, prácticas y discursos políticos en escena, conformando un horizonte sumamente amplio y multidireccional del que todos los actores podían participar en medidas distintas, dependiendo de sus circunstancias y posibilidades. Por otro lado, para el periodo de independencia el significado de la política parecía estar relacionado con lo que Joan Scott (2012, p. 69) entiende como su sentido más tradicional: de pertenencia al Estado,

\section{()(1) $\$$}


a la nación-Estado y a las autoridades que derivan de ellos. Aunque durante la independencia no puede hablarse de un Estado o nación como tal, y quizá ni siquiera de un gobierno o, en todo caso, no de uno solo, lo político se entendió como aquello que tenía que ver con el poder para organizar al conjunto de la sociedad y con los grupos que contaban con los medios para ejercerlo y disputarlo.

En este contexto, es riesgoso abordar a las mujeres como un colectivo con reivindicaciones comunes en torno a las cuales se organizaron, ${ }^{1}$ pues aunque las tuvieron, estas no cristalizaron en luchas colectivas, sino que se persiguieron individualmente, según las posibilidades que le brindaba a cada una su propia identificación con el significado abstracto de ser mujer. Podría argumentarse que no estaban en capacidad de una conciencia política al no contar con una lucha común que la sustentara, pero al tiempo que percibieron el conflicto como mujeres, también lo hicieron desde otras posturas, compartiendo luchas, organizaciones e identificaciones con los hombres a partir de la estratificación social, los lazos familiares, la filiación política y muchos otros factores distintos del género. ${ }^{2}$ Por otro lado, la conciencia política no necesariamente implicaría una toma de partido ni se traduciría en acciones políticas concretas, enfoque que permite recuperar sentidos políticos distintos del apoyo a las facciones, visibilizando actores que de otro modo quedarían descartados como agentes políticos, por ejemplo aquellas mujeres que no favorecieron una causa y se mantuvieron alejadas del conflicto en cuanto les fue posible. Así, las mujeres construyeron su conciencia política a partir de una mirada particular, condicionada por el género más no determinada por él, que no era radicalmente aislada o distinta de la del resto de la población, y que no por producirse fuera de una lucha colectiva, manifestarse individualmente o mantenerse al margen de la adhesión a una causa dejó de tener connotaciones políticas. Por otro lado, la construcción de dicha conciencia no respondió únicamente a la cultura política, sino también a las experiencias vividas, a la violencia y devastación

${ }^{1}$ Existe un debate sobre si durante el periodo de independencia las mujeres se organizaron para exigir mayores derechos y libertades de los que ya tenían (Cherpak, 1995, p. 84; González, 2010, pp. 5-6; Lux, 2014, pp. 153-214).

${ }^{2}$ Scott (1991, pp. 76-82) advierte sobre el riesgo de entender a las mujeres como una categoría homogénea, con una esencia que las une en una cultura femenina y experiencia femenina compartida, en una identidad colectiva con necesidades y características intrínsecas.

\section{()(1) $\$$}


de la guerra, a intereses económicos, familiares, emocionales, a características particulares relacionadas con su posición socioeconómica o su nivel educativo, entre muchos otros factores, que instaron a los actores sociales a adaptarse estratégicamente según las circunstancias, constituyéndose como sujetos volubles e inestables. ${ }^{3}$

\section{LAS MUJERES EN EL CONTEXTO DE LA INDEPENDENCIA DE NUEVA GRANADA}

La crisis de la monarquía española producida tras el destronamiento de Fernando VII por las fuerzas napoleónicas tuvo serias repercusiones en ultramar, donde numerosas poblaciones establecieron sus propias juntas de gobierno al estilo de las creadas en España como complemento de la rebelión popular contra los invasores, que se abocaron la soberanía que en ausencia del rey debía regresar al pueblo. Las juntas neogranadinas que proliferaron en 1810 (la de Santafé se estableció el 20 de julio de ese año) generalmente estuvieron encabezadas por las elites criollas y se conformaron después de levantamientos populares. Aunque en principio no tenían intenciones separatistas sino autonomistas, socavaron la autoridad virreinal y empezaron a albergar proyectos independentistas. Surgieron dos facciones revolucionarias opuestas, a pesar de reconocerse ambas como republicanas y patriotas, debido a rivalidades regionales y a las miras federalistas y centralistas de una y otra. Se trataba respectivamente de la Federación de las Provincias Unidas de la Nueva Granada y del Estado de Cundinamarca con sede en Santafé, que mantuvieron constantes enfrentamientos entre sí alcanzando las dimensiones de una guerra civil, al tiempo que continuaron luchando contra los reductos realistas que quedaban (Martínez, 2007a, 2007b; Reyes, 2010). Tras recuperar el trono en 1814, Fernando VII envió un ejército a América con el fin de aplastar la revolución. El destacamento destinado a Nueva Granada arribó allí en 1815 y logró recuperar el territorio rápidamente, ya que las tro-

${ }^{3}$ De manera similar entienden a los actores sociales Orrego, Aljovín y López (2009, p. 12): zigzagueando de un lado al otro, forzados por las sucesiones violentas y rápidas de los acontecimientos a efectuar cambios políticos drásticos de apariencia contradictoria, con una constante variabilidad de posiciones en lapsos efímeros de tiempo.

\section{(ㄷ)(1) $\$$}


pas y líderes republicanos se dispersaron y huyeron al reconocerse incapaces de afrontar la avanzada realista. En mayo de 1816 Santafé fue tomada, el virreinato fue restablecido y se emprendió una cruzada judicial contra cabecillas y colaboradores de la revolución. Vale la pena destacar el establecimiento en la capital de tres temidos tribunales: el Consejo Permanente de Guerra se ocupaba de los casos más graves de sedición y dictaba las sentencias de muerte; el Consejo de Purificación se encargaba de aquellos que no se habían visto tan comprometidos con la sedición, determinaba su grado de compromiso y permitía purgarlo por medio de castigos como multa, destierro o prisión; la Junta de Secuestros tenía como tarea confiscar los bienes de los insurgentes y asegurar el pago de las multas (Páramo, 2010). A principios de 1819 dio comienzo la llamada Campaña Libertadora, adelantada por tropas venidas desde Venezuela al mando de Simón Bolívar, que en Nueva Granada se unieron a las fuerzas rebeldes que aún presentaban resistencia al régimen realista, especialmente en forma de guerrillas. La Campaña consiguió rápidas victorias sobre los ejércitos españoles, recuperó gran parte del territorio neogranadino, y en septiembre de ese mismo año retomó Santafé, estableciendo luego un sistema de gobierno republicano.

Este conflicto, que se prolongó por varios años, involucró tensiones e intereses de muy diversa índole: disputas por el poder entre elites criollas y funcionarios españoles, desconfianza en las improvisadas instituciones peninsulares leales al rey y desencanto frente a la escasa representación americana que convocaron, oposición entre facciones revolucionarias, descontento popular con la guerra y los abusos de los gobiernos, insatisfacción de los grupos menos favorecidos que adelantaron sus propias luchas al no verse representados en las propuestas políticas de los bandos, pugnas de carácter nacionalista entre España y los nacientes Estados americanos. Fue un periodo de intenso debate político en que se involucraron nuevos espacios de discusión y nuevos actores, se cuestionaron las bases de la legitimidad política, se ensayaron nuevos conceptos, discursos y proyectos políticos como soberanía del pueblo, ciudadanía y república, se evidenciaron rivalidades regionales y tensiones sociales entre distintos sectores de la población. Fue lo que Fernández (2009, pp. 25-43) ha llamado laboratorio político y conceptual. Un momento de indefinición política en que el significado mismo de lo político fue constantemente reformulado por los distintos actores según sus necesidades e intereses. Por otro lado, las facciones enfrentadas trajeron la

\section{()(1) $\$$}


guerra y la devastación, exigieron altas contribuciones económicas, realizaron reclutamiento forzado, instaron a guardar fidelidad o amenazaron con la represión. Esto llevó a la politización de hombres y mujeres que se vieron obligados a definir sus lealtades y actuar estratégicamente para verse lo menos perjudicados posible. ${ }^{4}$

La posición de las mujeres en el conflicto fue ambigua. El ideal femenino de buenas madres y esposas recluidas en el espacio doméstico fue ampliamente transgredido. Se les atribuían funciones de transmisión de valores y tradiciones, fundamentales para las políticas de poblamiento y asentamiento en el Nuevo Mundo (Condés, 2002, pp. 15-16). Se les exigía castidad, fidelidad, recato y sumisión al tiempo se les tildaba de concupiscentes, inmorales, irresponsables, incapaces de responder por sí mismas e inferiores a los hombres en todo sentido. Por esta razón quedaron supeditadas a la tutela masculina, especialmente del padre o el esposo, y se les impusieron numerosas restricciones de tipo civil, sexual, educativo y económico, entre otros. ${ }^{5}$ Aunque se consideraban ajenas a los asuntos públicos y políticos, tuvieron una participación activa y masiva en luchas y debates: se desempeñaron como espías, auxiliadoras de las tropas, combatientes, financiadoras, conspiradoras, manifestantes, etc., rebasando sus papeles tradicionales y las restricciones que tenían impuestas. Esto obligó a las autoridades a modificar su concepción tradicional sobre ellas, reconociendo lo fundamental de su participación hasta el punto de modificar su legislación para asegurar que recibieran castigos tan duros como los que recibían los hombres (Brewster, 2005 , p. 20) y de convocarlas para defender la causa. Ellas atendieron al llamado, aprovecharon todo resquicio político para expresar sus opiniones y convicciones y conquistaron espacios anteriormente vedados para ellas. Al mismo tiempo, debieron enfrentar la guerra y la represión y perder sus fortunas y sus seres queridos, de manera que sus respuestas parecieron obedecer más a cuestiones estratégicas y oportunistas para conservar la bolsa y la vida que a ideales políticos.

${ }^{4}$ Para el caso de México, Garrido (2013, pp. 61-64) y Pani (2009, p. 40) señalan la politización de la población que se produjo ante las exigencias de las facciones.

5 Sobre la condición de las mujeres en la colonia y el siglo xIX, véase Bermúdez (1995); Bermúdez (2001); Ramírez (2002).

\section{()(1) $\$$}




\section{FUENTES PARA EL RASTREO DE LA CONCIENCIA POLÍTICA}

El conjunto documental que sustenta este trabajo consta de varias peticiones elevadas por 73 mujeres a las autoridades de corte republicano o realista que se sucedieron en la ciudad de Santafé entre 1810 y 1820 . Desde el periodo colonial este tipo de documento estuvo relacionado con la impartición de justicia, ya que se configuró como una salida para aquellos que se sentían vulnerados y necesitados de la intervención gubernamental. No fue un recurso utilizado únicamente por actores marginados de la sociedad, sino también por poderosos que veían afectados sus intereses. Para ampliar las posibilidades de recibir una respuesta positiva a sus demandas los peticionarios se valieron de distintas estrategias: se adaptaron a los lenguajes y fórmulas legales, a los discursos dominantes y a las expectativas de las autoridades, se mostraron obedientes y leales a ellas, exageraron o alteraron los hechos que describían para darle mayor dramatismo y contundencia a sus argumentos. Resultó común que las peticiones no fueran elaboradas directamente por los interesados, sino por personajes con el conocimiento legal necesario para presentar argumentos convincentes e interponer y dar seguimiento a los procesos, por ejemplo líderes de la comunidad, escribanos, procuradores, apoderados legales o abogados. En todo caso, a través de estos documentos logran traslucirse con precisión los reclamos y solicitudes de los peticionarios, e incluso sus críticas y amenazas veladas a las autoridades. Estas últimas se vieron obligadas a atender sus demandas, al menos en los casos en que no hacerlo las haría parecer injustas y comprometería su legitimidad. ${ }^{6}$

Para México, Silvia Arrom (1998) señala que las peticiones eran la principal arma política de las mujeres. Durante el periodo colonial se presentaron más que todo como solicitudes de individuos aislados con objetivos estrictamente personales, pero después de la independencia empezaron a ser presentadas por colectivos de mujeres que hacían demandas a los nue-

${ }^{6}$ Varios autores han hecho uso de este tipo de fuente para rastrear la cultura política, los puntos de vista, las nociones sobre justicia, las expectativas, entre otros aspectos, de distintos grupos sociales, y han reflexionado y teorizado sobre ello. Véase Garrido (1993); López (2006); Owensby (2011); Villegas (2006) y especialmente Falcón (2006).

\section{(ㅇ)(1) $(9$}


vos Estados (pp. 57-59). Las peticiones estudiadas en el presente artículo se presentaron en su mayoría de manera individual y nunca como colectivo de mujeres. Esto no les impide evidenciar cuáles podían ser las principales preocupaciones de la población femenina afectada por el contexto de guerra e inestabilidad política del momento. Aunque recibidas como documentos independientes, llegaron a ser tan comunes y numerosas que desafiaron y rebasaron las capacidades de las autoridades. Para el caso de la independencia en Sudamérica, Evelyn Cherpak (1995, p. 109) señala que las mujeres abrumaron a las autoridades realistas con peticiones concernientes a la libertad de sus maridos. Peticionar no fue una innovación de ese periodo, era una tradición de larga data. Así lo evidencia la orden emitida por el gobierno monárquico en 1797, en la que "deseando el rey cortar de una vez un abuso tan perjudicial", se prohibía promover solicitudes a las madres, esposas e hijas de militares. En caso de que reincidieran, tampoco tendrían validez las solicitudes hechas por los propios militares. Sólo se atenderían aquellas que se recibieran por conducto de los jefes de cada interesado. Esta orden fue refrendada en 1799, en 1801, en 1803, en 1804, y también en pleno tiempo de guerra, en 1814 y 1817. ${ }^{7}$ Esta situación no indispuso únicamente a las autoridades realistas. Martha Lux (2014, p. 206) señala que fueron muy numerosas las peticiones de mujeres dirigidas a los republicanos para interceder por sus hijos y esposos, y le causaron complicaciones al gobierno, que en vano intentó desestimularlas. Esta práctica persistió más allá de la consolidación de la república, como lo demuestran los trabajos de Pamela Murray (2009) y Alonso Valencia (2001, pp. 135-156) sobre peticiones de mujeres a personajes políticos importantes durante la segunda mitad del siglo XIX.

Las peticionarias neogranadinas no se redujeron a pedir por sus familiares. Además de solicitar la atenuación o anulación de penas impuestas a sus parientes y a ellas mismas por haberse involucrado de alguna manera con el bando enemigo, también solicitaron el pago de limosnas, pensiones, deudas u otras obligaciones económicas contraídas por el gobierno, etc. Para ellas lo político cobró sentido principalmente en la medida en que

${ }^{7}$ Copia de real orden prohibiendo a las mujeres parientes de militares ir personalmente a la Corte a tramitar peticiones. 23 de diciembre de 1817. Fondo Consejo de Medellín. Sección Colonia. Serie Órdenes. T. 88, f. 198r.-198v. Archivo General de la Nación (AGN), Colombia.

\section{()(1) $(9$}


afectó sus vidas o les permitió negociar con otros actores sociales la solución de los problemas causados por la guerra y la incertidumbre política. Aunque su objetivo no era el de discutir materias políticas, profirieron numerosas referencias de esta índole que evidencian los lenguajes y conceptos políticos que manejaban. Para procurar el éxito de sus peticiones se adaptaron a los discursos políticos dominantes y se mostraron fieles a la causa de turno. Por ejemplo, de 36 mujeres que se dirigieron a las autoridades en el primero y segundo periodo republicano, 16 le dieron el apelativo de ciudadano a uno o varios individuos y catorce se identificaron a sí mismas como ciudadanas. En cambio, ninguna de las 40 mujeres que se dirigieron a las autoridades realistas hicieron referencia a la ciudadanía, y prefirieron presentarse a sí mismas y a otros como vecinos y vasallos. También se adaptaron a los patrones de género aceptados por las autoridades y se mostraron apegadas al ideal femenino. Usaron la estrategia discursiva del lamento, que encajaba perfectamente con la idea de mujer como sexo débil (Lux, 2011, p. 150) y resaltaron su condición de madres y esposas desvalidas, que necesitaban del apoyo masculino o gubernamental para asegurar la subsistencia de su familia. La formulación de peticiones también se vio condicionada por aspectos que trascendían la política y el género, como la adscripción étnica, el estado civil, el nivel socioeconómico, etc. Por ejemplo, las mujeres de clases altas pudieron tener mayores posibilidades de peticionar, por contar con los recursos necesarios para dar seguimiento a los procesos y contratar asesores legales. Las de escasos recursos tuvieron que recurrir a otro tipo de mecanismos, como solicitar ser eximidas de ciertos costos inherentes al trámite o recurrir al procurador de pobres, funcionario encargado de representar a quienes no podían pagar un abogado particular (González, 2012). Ejemplo de lo anterior es Francisca Villamil, quien pedía que su petición le fuera recibida "en este papel porque mi notoria pobreza no me permite hablar en otro", y había sido representada por el procurador de pobres José Antonio Cortés. ${ }^{8}$

No había una única forma de ser mujer en la época; dependiendo de las circunstancias específicas de cada una la categoría abstracta de mujer se

${ }^{8}$ Francisca Villamil solicita se le conceda la libertad a su hijo José María, quien se encuentra preso. 25 de abril de 1818. Sección Archivo Anexo. Fondo Purificaciones. T. 12, f. 153bisr.-153bisv. AGN, Colombia.

\section{()(1) $\$$}


llenaba con significados diferentes, en función de los cuales ellas tuvieron que modular sus discursos y prácticas. Sin embargo, las fronteras entre un tipo de mujer y otro no siempre fueron claras. Así lo evidencia el caso del procurador de pobres Nicolás Llanos, quien sirvió a nueve de las 73 peticionarias. Entre sus representadas se encontraban desde las tenderas Ana María de la Rocha y Mariana Duarte, hasta las distinguidas Petronila Nava e Isabel Caicedo, pertenecientes a familias ilustres de criollos reconocidos por su apoyo a la independencia y afectados por las confiscaciones y fusilamientos. ${ }^{9}$ En una de sus peticiones Isabel Caicedo incluso afirmaba que para sobrevivir había tenido que ejercer el oficio de panadera que era desconocido para ella y superior a sus fuerzas. ${ }^{10}$ Según esto, el contexto de guerra había igualado hasta cierto punto a mujeres de clases medias, populares y trabajadoras con mujeres de clases pudientes caídas en desgracia, que, eventualmente, habían tenido que aprender a ganarse la vida con su trabajo. Tampoco resultaban claras las fronteras entre los argumentos utilizados por hombres y por mujeres. Ejemplo de ello son la petición de Josefa Algarra, dirigida a la facción centralista de las autoridades republicanas en 1812, y la de su hijo, José María Triana, dirigida a las autoridades realistas en 1816, como parte de su proceso de purificación. ${ }^{11}$ Algarra solicitaba ser liberada del de-

${ }^{9}$ Mariana Duarte González, vecina de esta ciudad, residente en el sitio de Cuatro Esquinas solicita licencia para instalar allí una venta sin perjudicar el Camino Real. Julio de 1818. Sección Archivo Anexo. Fondo Solicitudes. T. 11, fs. 96r.-128v. AgN, Colombia; Ana María de la Rocha: solicita se le cancele el dinero que le adeudan. 1816-1819. Sección Archivo Anexo. Fondo Solicitudes. T. 3, fs. 793v.-794v. Agn, Colombia; Solicitud que hace Petronila Nava, viuda de Francisco García Hevia, sobre reclamo de la mitad de ganancias del caudal que dejó su esposo. Junio de 1817. Sección Archivo Anexo. Fondo Solicitudes. T. 9, fs. 301r.342v. AGN, Colombia; Isabel Caicedo, vecina de esta capital expone sobre su extrema pobreza y solicita alguna ayuda. Abril de 1818. Sección Archivo Anexo. Fondo Solicitudes. T. 11, fs. 677r.-688v. AGN, Colombia.

${ }^{10}$ Comunicación enviada por Isabel Caicedo, viuda del general Antonio Baraya, fusilado por el general Pablo Morillo, quien fue despojada de todos y cada uno de los bienes dejándola en la absoluta miseria. 2 de octubre de 1819. Sección Archivo Anexo. Fondo Historia. T. 26, f. 717r.-717v. AGN, Colombia.

${ }^{11}$ Expediente seguido en el Tribunal de Vigilancia y Seguridad de Santafé en contra de Manuel Triana y su esposa Josefa Algarra. 1812. Sección Archivo Anexo. Fondo Historia. T. 14, fs. 596r.-623v. AgN, Colombia. Expediente de purificación de don José María Triana, vecino de Santa Fe. Junio 28 de 1816. Sección Archivo Anexo. Fondo Purificaciones. T. 1, fs. 491r.-502v. AGN, Colombia.

\section{()ㅜ(1) $\$$}


pósito preventivo que se le había impuesto a causa de una carta que Triana, partidario de la facción federalista, le había enviado a ella y a su esposo. Ella deseaba regresar a casa para cuidar a sus desconsolados hijos (entre ellos niños pequeños y mujeres que podían correr todo tipo de peligros), a los que había tenido que abandonar desde hacía mucho tiempo. Triana solicitaba que su conducta durante la revolución fuera purificada, y para librarse de represalias argumentaba que a la muerte de sus padres él había relevado el papel de padre de familia, y que tenía que velar por siete hermanos pequeños, entre ellos cinco niñas a las que debía mantener, por no haberles dejado sus padres ninguna herencia y sí muchas deudas. Ambos intentaron justificar sus peticiones haciendo referencia a sus obligaciones familiares. En este punto parece importante reconocer la potencialidad del género no sólo para señalar las diferencias entre hombres y mujeres, sino también para delimitar hasta dónde llegaban esas diferencias y cuáles eran las similitudes. Además, reconocer que el género no era el único elemento, ni necesariamente el más importante, a la hora de condicionar las ideas y las prácticas femeninas y masculinas. En el caso de Algarra y Triana, por ejemplo, parecían primar las condiciones familiares.

Es probable que la mayoría de las peticionarias recurrieran a intermediarios que las asesoraran en la elaboración de sus peticiones y las representaran en la tramitación de las mismas ante las autoridades. Esto en razón de que, al igual que muchos otros actores, probablemente las mujeres no tenían un conocimiento detallado de los parámetros y estrategias legales conocidas por los abogados y procuradores $\mathrm{u}$ otros profesionales y funcionarios. Más aun cuando a ellas les estaban vedados este tipo de empleos, su educación, cuando la recibían, estaba orientada a prepararlas para el matrimonio, y se esperaba que se encontraran en todo momento bajo algún tipo de tutela masculina. Resulta complicado determinar el grado de intervención que tuvieron tanto las mujeres como sus asesores legales en la elaboración de las peticiones. Determinar si la letra de la petición coincide con la de la mujer firmante resulta insuficiente para afirmar que fue completamente de su autoría, pues aun si la escribió de su puño y letra el contenido pudo ser influenciado o sugerido por otros. Por otro lado, si se estableciera que la letra es la del asesor que firma junto a la mujer, tampoco podríamos estar seguros de que ella no participó en la elaboración de los argumentos. Identificar uniformidades en el lenguaje, que sugieran la uti-

\section{()(1) $\$$}


lización de fórmulas retóricas oficiales, tampoco asegura que las peticiones que no las siguieron tuvieran mayores probabilidades de haber sido concebidas por las mujeres, al suponerles un conocimiento limitado de dichas fórmulas. Es posible que ellas las hubieran conocido si, por ejemplo, tenían contacto constante con profesionales de las leyes o recurrían a la petición regularmente, o que el conocimiento de sus asesores en la materia fuera limitado si, en vez de ser sus abogados, eran sus vecinos, amigos o parientes que les hacían el favor de representarlas o tenían la obligación de hacerlo. Tampoco se puede asegurar que las mujeres de clases populares, por tener menos recursos para contratar asesores, se vieron más comúnmente obligadas a escribir sus propias peticiones, pues entre más bajo fuera su nivel socioeconómico menos posibilidades tenían de ser letradas o alfabetas, y además podían recurrir a los procuradores de pobres. Ante esto resulta necesario reconocer, como lo hace Romana Falcón (2006, pp. 477-478) para las peticiones de grupos marginados de la segunda mitad del siglo xIX mexicano, la imposibilidad de saber con certeza el papel de los intermediarios en la elaboración de estos documentos. Parece más factible, antes que determinar el grado de intervención de autoridades, intermediarios y mujeres en su formulación, así como la coincidencia de su contenido con la realidad, identificar de qué forma se hizo posible que las mujeres hablaran sobre política en su interacción con las autoridades. Lo anterior no debe llevarnos a concluir que ellas no estuvieron en capacidad de manejar los argumentos contenidos en sus peticiones. Resulta difícil imaginar, aun en los casos en los que tuvieron poca o nula intervención en la formulación de tales documentos, que las peticionarias no hayan podido o no hayan querido enterarse de su contenido para darle su visto bueno, precisar la información, hacer sugerencias o desaprobarlo en caso de considerarlo inconveniente $y$, aunque fuera de esa manera indirecta, hayan participado de la cultura, los conceptos y lenguajes políticos de su época. También resulta difícil suponer que ellas lograron mantenerse al margen de los mismos en un contexto en el que, como lo señala María José Garrido (2013, pp. 63-64) para el caso de México, la guerra y la transformación de las ideas obligó a la población a tomar partido y a politizarse, y los temas políticos estuvieron a la orden del día y presentes en todos los espacios públicos, muchos de los cuales eran visitados asiduamente por las mujeres.

\section{()(1) $\$$}




\section{LA CONCIENCIA POLÍTICA SOBRE EL COMPLEJO SIGNIFICADO DE LA CONDUCTA POLÍTICA}

Un aspecto sobresaliente que quedó consignado en las peticiones analizadas es el complejo significado que se dio a la conducta política. Para ilustrarlo podemos valernos del caso de tres mujeres que en 1816 solicitaron a las autoridades realistas que les realizaran un proceso de purificación, para comprobar que no habían tenido un comportamiento sedicioso durante la revolución, y lograr la revocación de los destierros que se les habían impuesto. En primer lugar está María Dolores Rodríguez, quien pidió a los testigos de su defensa que dieran información acerca de su conducta política, costumbres, opinión, dichos y hechos. Ellos coincidieron en que era afecta al realismo y enemiga de los rebeldes, había ayudado a los perseguidos por el gobierno insurgente, había tenido una conducta arreglada y honrada, manteniéndose con su trabajo personal. Rodríguez añadía que cualquiera a quien se le preguntara la calificaría de mujer quieta y retirada. ${ }^{12}$ En segundo lugar está Mariana Duarte, intercediendo por su hija María Regina Miranda, pidiendo a los testigos que declararan acerca del carácter, honradez y natural moderación de esta, a quien describía como incapaz de mezclarse en tumultos y partidos. Los testigos coincidían en que vivía con honradez, retirada en casa, sin mezclarse en tumultos ni partidos, con un modo de pensar pacífico, moderada, incapaz de ofender a alguien y no odiosa a la sociedad. ${ }^{13}$ Por último, María Riveros manifestaba que su trabajo de revendedora la obligaba a salir a las plazas y que sólo había empezado a ejercerlo después de que el jefe republicano Simón Bolívar entrara en la ciudad, pero más allá de eso nunca se había mezclado en otras cosas y su conducta había sido irreprensible. Solicitaba a los testigos que informaran si era mujer escandalosa y tumultuaria, a lo que ellos respondieron que era una buena mujer, no afecta a mezclarse en tumultos, que no había sido escandalosa ni quemerista. ${ }^{14}$

\footnotetext{
12 Expediente de purificación de doña Dolores Rodríguez, vecina de Santafé. 27 de junio de 1816. Sección Archivo Anexo. Fondo Purificaciones. T. 1, fs. 483r.-487r. Agn, Colombia.

${ }^{13}$ Expediente de purificación de doña María Regina Miranda. 1 de julio de 1816. Sección Archivo Anexo. Fondo Purificaciones. T. 1, fs. 516r.-519r. AGN, Colombia.

${ }^{14}$ Expediente de purificación de María Riveros vecina de Soatá. 16 de agosto de 1816. Sección Archivo Anexo. Fondo Purificaciones. T. 2, fs. 31r.-32r. Agn, Colombia. El término
} 
De los ejemplos anteriores se infiere que para las peticionarias una conducta política adecuada estaba relacionada con diversos factores: cuando se hablaba de honradez parecía adquirir connotaciones morales. Cuando se hablaba de sobrevivencia a partir del propio trabajo parecía adquirir matices laborales. Cuando se hablaba de participación en tumultos, escándalos y quemerismo en sentido negativo, y de conducta arreglada, modo de pensar pacífico, natural moderación y obediencia en sentido positivo, la conducta política parecía referirse al buen o mal comportamiento de un vasallo. Cuando se hablaba de asegurar la manutención de la familia, de buena mujer, quieta y retirada en casa, incapaz de mezclarse en tumultos y partidos, la conducta política parecía adquirir matices de género en la medida en que aludía al ideal de mujer encargada de la familia, recluida en los espacios domésticos, pasiva y ajena a los espacios públicos, debates y conflictos políticos. El género como condicionante de la conducta política también se evidencia en la petición de Ignacia Silva, quien en 1816 solicitó a las autoridades realistas la excarcelación de su marido bajo fianza, y pidió a los testigos información sobre la conducta, procedimientos y hombría del mismo. ${ }^{15}$ Aquí la hombría aparecía como una prueba más de la buena conducta de su esposo.

Aunque Rodríguez y Riveros no cumplían a cabalidad el ideal femenino, pues ejercían oficios que las obligaban a salir de casa, parecieron querer contrarrestar esta condición presentándose como viuda y pobre, respectivamente, y resaltando la laboriosidad que las caracterizaba, la cual parecía corresponderse con las políticas contra la vagancia y la ociosidad adelantadas tanto para el gobierno monárquico como el republicano. ${ }^{16}$ Por otro lado, parecía existir una relación entre la conducta política y las prácticas en los espacios privados, posiblemente en el sentido de que mantener el orden en lo privado ayudaba a mantenerlo también en lo público. Cuando Ramírez y

quemerista parece hacer referencia a la participación en ceremonias de quema de retratos reales utilizada como forma simbólica de rechazar la autoridad real. Sobre este tema, véase Gutiérrez (2014, pp. 5-37).

${ }^{15}$ Ignacia Silva, esposa de Carlos Fernández, preso en la cárcel de Corte, solicita para este la excarcelación. 3 de julio de 1816. Sección Archivo Anexo. Fondo Solicitudes. T. 6, fs. 17r.-19r. AGN, Colombia.

${ }^{16}$ Sobre el combate de la vagancia en el siglo xix, véase Botero (2012).

\section{()(1) $(2$}


Miranda se mostraron como mujeres retiradas en sus casas posiblemente lo hicieron bajo la idea de que su reclusión en el espacio privado era sinónimo de una buena conducta política. La petición de Manuela Marcón también evidencia este tipo de relación, cuando en 1819 solicitó a las autoridades republicanas que su marido fuera puesto en libertad, para lo cual pedía que se recibiera información acerca de su conducta tanto pública como privada. ${ }^{17}$ La conducta política también podía estar condicionada por la estratificación social y la edad. Así lo evidencia la petición de Ignacia Uribe, quien en 1817 solicitó a las autoridades realistas que liberaran al paje que acompañaba a su hermano cuando ambos fueron capturados, pues "vasta verle, para conocer, que es un mozo que solo tiene la edad de diez a doce años, y que tanto por esa causa, como por ser criado en el campo, y de una extraccion comun, es absolutamente incapaz de haber sido criminal". ${ }^{18}$ Aquí la minoría de edad, la procedencia rural y la pertenencia a las clases populares acreditaban la inocencia del niño, en un contexto donde las elites habían sido las principales promotoras de la revolución.

La conducta política parecía operar bajo una visión integral del individuo, en donde una persona que tenía una conducta adecuada en el ámbito privado, laboral, moral, de género y de estratificación social, entre otros, se suponía que debía tenerlo también en el político. Para puntualizarla parece apropiado retomar lo político en su acepción de conservación del orden establecido, donde una buena conducta significaba colaborar en la medida de lo posible a dicha conservación en cualquiera de sus dimensiones. Esto, en vez de suponer una despolitización de la conducta política a causa de la naturaleza diversa de sus componentes, invita a complejizar el significado que tenía la política en ese momento, pensando dichos componentes no como condicionantes sino como constitutivos de la misma.

17 Manuela Marcón, vecina de Málaga y esposa legítima de Jerónimo Castellanos, quien se encuentra preso, solicita para este la libertad. 1819. Sección Archivo Anexo. Fondo Solicitudes. T. 15, f. 312r.-312v. AGN, Colombia.

${ }^{18}$ Ignacia Uribe, vecina de esta ciudad solicita se le conceda la libertad a Ignacio Mojica, quien se encuentra preso en el Colegio del Rosario. 25 de febrero de 1817. Sección Archivo Anexo. Fondo Solicitudes. T. 8, f. 243r.-243v. Agn, Colombia.

\section{()(1) $\$$}




\section{LA CONCIENCIA POLÍTICA SOBRE EL BUEN GOBIERNO}

Durante el periodo de independencia las mujeres reflexionaron sobre el comportamiento adecuado o inadecuado de las autoridades, materia ligada al buen gobierno en su acepción de trato justo por parte de los gobernantes a sus gobernados, con el fin de asegurar la lealtad de estos últimos y evitar el menoscabo de su legitimidad política. ${ }^{19} \mathrm{El} \mathrm{hecho} \mathrm{mismo} \mathrm{de} \mathrm{que} \mathrm{las} \mathrm{mujeres}$ se decidieran a interponer peticiones revela que no se sentían satisfechas con el quehacer de las autoridades, y así lo manifestaron explícitamente al denunciar malos manejos y abusos por parte de instituciones y funcionarios. Es el caso de María Francisca Solórzano, quien en septiembre de 1819 solicitó a los republicanos que obligaran al capitán Juan José Reyes a entregarle los bienes que su marido le había encargado dar a ella después de su muerte. Solórzano exigía la devolución apelando a que "la justicia, la razon, y las concideraciones todas apoyan esta solictud, demandando que el Capitan Reyes sea extrechado a la entrega, en fuerza del encargo que abrazó". ${ }^{20}$ De manera similar, Margarita Liz solicitó en 1817 a los realistas que libraran una providencia a los alcaldes de la villa de Purificación, quienes al parecer le exigían constantemente contribuciones en ganado, "para que se me distinga segun el nacimiento de mi cuna y que no me lleben con tanto rigor". ${ }^{21}$ Aunque las mujeres denunciaron a funcionarios específicos en casos concretos, más que mostraron una abierta oposición a un sistema de gobierno particular, no establecieron una clara diferenciación entre las medidas perjudiciales que emanaban directamente de la voluntad gubernamental y las que se deformaban en manos de los funcionarios que las llevaban a la práctica. En todo caso, ya emanadas de los jefes políticos o tergiversadas por sus subordinados, (2011).

${ }^{19}$ Sobre el significado de buen gobierno en ese periodo, véase Bernal (1989); Pulido

${ }^{20}$ Francisca Solorzano, viuda del coronel Antonio Arredondo solicita se le entregue el contenido de unos baúles pertenecientes a su marido. Septiembre de 1819. Sección Archivo Anexo. Fondo Solicitudes. T. 15, f. 402r.-402v. AgN, Colombia.

${ }^{21}$ Margarita Liz solicita que los alcaldes de esta villa, Marcos Villegas y Julián Parga, la traten con la consideración debida a sus circunstancias. 28 de agosto de 1817. Sección Archivo Anexo. Fondo Solicitudes. T. 10, f. 63r.-63v. AGN, Colombia.

\section{()(1) $\$$}


cuando las medidas se consideraban excesivas las calificaban como abuso y no alcanzaban a quedar justificadas por la justa causa. Por eso Solórzano manifestaba que "por mas que gustosa haga el sacrificio de padecer orfandad a beneficio de la causa; no puedo menos, que tratar de la subsistencia propia, y la de un hijo havido en el matrimonio"22 y Liz manifestaba que "yo no intento en reusarme de serbir a Nuestra Catolico Monarca [...] con todos los bienes pero no tanto estremo y tropelia de dichos Alcaldes, sin atender a los fueros y privilegios que goza por Nuestro Soberano una señora viuda de mi naturaleza". ${ }^{23}$

De un buen gobierno se esperaba que retribuyera la fidelidad y servicios que le habían prestado sus gobernados. Así lo sugiere el caso de Ana María de la Rocha, quien entre 1816 y 1818 elevó ocho peticiones a las autoridades realistas solicitando el pago de las mercancías tomadas de su tienda para uso de las tropas del rey. Rocha explicaba que dichas mercancías "las franquié gustosamente por haber sido para servicio [de] las tropas de su magestad", y resaltaba que "se consumieron en el servicio de la real Corona". En un interrogatorio realizado al funcionario encargado del transporte de las mercancías, este declaraba que Rocha había accedido a entregarlas a bajo precio "por mucho favor y amistad y en concideracion a ser para el servicio del Rey". La deuda debía ser saldada porque se había comprobado que era legítima pero, además, el hecho de que hubiera sido en función de las tropas reales y, por lo tanto, de la causa realista, le daba un carácter de mayor compromiso. Hasta los jueces parecían ser conscientes de ello. Así lo sugiere uno de los encargados del caso, quien aprobó su petición "no siendo justo que por mas tiempo caresca esta interesada de un suplemento que hizo para el servicio de las Tropas de su Magestad". ${ }^{24}$ Las mujeres apelaban no sólo por su propia fidelidad y servicios para justificar sus peticiones, sino también por los de sus parientes, es decir, reclamaron prerrogativas de

${ }^{22}$ Francisca Solorzano, viuda del coronel Antonio Arredondo solicita se le entregue el contenido de unos baúles pertenecientes a su marido. Septiembre de 1819. Sección Archivo Anexo. Fondo Solicitudes. T. 15, f. 402r. AgN, Colombia.

${ }^{23}$ Margarita Liz, solicita que los alcaldes de esta villa, Marcos Villegas y Julián Parga, la traten con la consideración debida a sus circunstancias. 28 de agosto de 1817. Sección Archivo Anexo. Fondo Solicitudes. T. 10, f. 63v. AGN, Colombia.

${ }^{24}$ Ana María de la Rocha, solicita se le cancele el dinero que le adeudan. 1816-1819. Sección Archivo Anexo, Fondo Solicitudes. T. 3, fs. 793v.-794v. AGN, Colombia.

\section{()(1) $(9$}


reciprocidad transferidas a ellas por medio de sus lazos de parentesco. Así lo evidencia Juana Martínez, quien en 1815 reclamó al Estado republicano de Cundinamarca la pensión de 60 pesos anuales en "premio al sacrifico hecho por mi marido", quien había "muerto en la Campaña de Venezuela en que se sacrificio dando un exemplo extraordinario de virtud y de patriotismo". ${ }^{25}$

Las peticionarias esperaban que las autoridades practicaran la caridad con los más necesitados, no como valor agregado sino como obligaciones genuinas de un buen gobierno, señaladas por las leyes. Así lo evidencia Ana María Lasquetty cuando en 1812 solicitó al gobierno republicano que la eximiera a ella y a su hermana de cierta contribución económica, y para justificar su solicitud identificó a ambas como huérfanas, enfermas, pobres e indigentes, sugirió que se les dieran las mismas consideraciones que a las viudas y manifestó que el "mismo estado que vela sobre los haveres Publicos, cuida de la subsistencia de las de mi clase. Si a estas les minorase sus cortos alimentarios intereses, se opondría a sus piadosos, y principales deberes." ${ }^{26}$ De manera similar, Isabel Caicedo en 1818, al no conseguir la devolución de su dote y bienes confiscados como si fueran de su marido, manifestó al funcionario realista encargado de su caso que "no dudo tendrá en consideracion los reputados encargos y aun privilegios que conceden las leyes en fabor de las viudas y personas miserables". ${ }^{27}$ También se esperaba que el gobierno exigiera a sus gobernados sólo en la medida en que su estado de vulnerabilidad se los permitía. Así lo sugiere la petición que en 1818 hizo Gabriela Barriga a las autoridades realistas para que, por hallarse muy pobre, la eximieran de la

${ }^{25}$ La viuda del capitán Antonio Ricaurte, Juana Martines Recaman, le escribe al presidente y a los miembros del poder ejecutivo de las Provincias Unidas de la Nueva Granada, rogando por la pronta entrega de las mesadas correspondientes a su pensión. 15 de febrero de 1815. Sección Archivo Anexo. Fondo Solicitudes. T. 15, f. 215. AGN, Colombia.

${ }^{26}$ Ana María Lasquetty y Juana, reclaman el pago de unos réditos donados a ellas por su hermano, Antonio Lasquetty. 14 de marzo de 1812. Sección Archivo Anexo. Fondo Solicitudes. T. 2, fs. 372r.-377v. AGN, Colombia.

${ }^{27}$ Isabel Caicedo, vecina de esta capital expone sobre su extrema pobreza y solicita alguna ayuda. Abril de 1818. Sección Archivo Anexo, Fondo Solicitudes. Tomo 11, f. 678r. AGN, Colombia. Sobre el concepto de persona miserable, véase Dougnac (1994, pp. 315-321). Vale la pena notar cómo el estado de viudez se asimilaba al de persona miserable.

\section{()(1) $(9$}


pensión de alojamientos, ${ }^{28}$ modalidad de contribución forzosa que consistía en alojar y alimentar a uno o varios soldados.

Las peticionarias manifestaron gran preocupación por la garantía de los bienes particulares y la recta administración de justicia penal. Esto suena lógico si se tiene en cuenta la presión económica que las autoridades ejercieron sobre la población en forma de confiscaciones y contribuciones forzadas y la represión que pusieron en práctica para combatir los brotes de insurgencia o contrainsurgencia. De 73 mujeres 36 hicieron solicitudes materiales, como revocación de contribuciones forzosas, restitución de bienes o pago de obligaciones económicas del gobierno. Del total, 30 hicieron solicitudes referentes a su situación judicial, la de sus parientes y, en menor medida, la de personas ajenas a su familia, como anulación de castigos, mejoramiento de las condiciones del reo o comprobación de que sus cuentas con los tribunales estaban saldadas. La ya mencionada Isabel Caicedo ejemplifica los reclamos de tipo económico. Ante la negativa del tesorero de la junta para hacer la devolución de su dote y bienes debido a insuficiencia de fondos, Caicedo respondió que "si el tesoro de los secuestros está agotado, sin duda lo ha sido en servicio de la Corona, y con calidad de devolver siempre lo que legitimamente correspondiese a los particulares, y con preferencia a los que por su carácter de miserables son privilegiados por la ley. Nada más digno, ni más propio de un Gobierno fundado en la equidad y la pública confianza." ${ }^{29}$ Por su parte, en octubre de 1819 Mariana Mendoza se dirigió a las autoridades republicanas para quejarse de que los recién derrotados realistas le habían quedado debiendo tres años de arrendamiento de la casa que pertenecía a su esposo y servía como palacio de gobierno. Esperando que el nuevo gobierno pagara por el poco tiempo que llevaba ocupando la misma casa, Mendoza decía que "la divina providencia ha querido que a aquel gobierno le susceda

28 Comunicación enviada por Gabriela Barriga, viuda de Antonio Villavicencio, en donde solicita se le exima el pago de la pensión de alojamiento por estar en un lamentable estado de pobreza. 2 de junio de 1818. Sección Archivo Anexo. Fondo Historia. T. 24, f. 10r. AGN, Colombia.

${ }^{29}$ Isabel Caicedo, vecina de esta capital expone sobre su extrema pobreza y solicita alguna ayuda. Abril de 1818. Sección Archivo Anexo. Fondo Solicitudes. T. 11, f. 678r. AgN, Colombia.

\section{()(1) $\$$}


uno equitatibo y liberal. Vuestra Excelencia está a la frente de el para dar a cada uno lo que en justicia le corresponde." 30

En cuanto a la administración de justicia penal, las peticionarias estuvieron interesadas en que los procesos judiciales se dieran dentro de los parámetros legales: que los casos fueran debidamente registrados y tomaran el tiempo estipulado por la ley; que los reos fueran informados del motivo de su castigo y recibieran un trato adecuado. Así lo evidencia la petición que hizo María de los Ángeles Ramírez en 1813 al presidente y miembros de la Junta de Justicia del Estado de Cundinamarca. Allí refería que se encontraba presa en la real cárcel de Zipaquirá desde hacía mes y medio sin que se le hubiera informado el motivo para ello, ni se le hubiera seguido causa o abierto sumario alguno. Se quejaba de que, además de haber aguantado una larga prisión, había tenido que soportar que el funcionario encargado de vigilarla la aporreara, la apaleara, la pusiera en el cepo y la metiera a un calabozo oscuro, sin importarle el estado de embarazo en que se encontraba. Ramírez acotaba que esto "no me parece justo, y mucho menos en un Gobierno justo, y liberal como lo es el de Cundinamarca". ${ }^{31}$

También estuvieron interesadas en que se lograra distinguir a los culpables de los inocentes, que los hechos delictivos se evaluaran de acuerdo con las circunstancias en que se habían producido, a los servicios que había prestado y la fidelidad a la causa que había manifestado el sindicado, a su estado de vulnerabilidad y el estado de vulnerabilidad en que quedaría su familia si le resultaban cargos. Esto con el fin de detectar cualquier posible atenuante de la pena y evitar que el reo recibiera un castigo peor del que merecía. ${ }^{32}$ Así lo sugiere la petición conjunta de Josefa Lozano y Concepción Racines, esposa y hermana de Antonio Racines, respectivamente, quienes en 1816 solicitaron a las autoridades realistas que este fuera dejado en libertad

30 Mariana Mendoza, solicita se le satisfaga el valor del arriendo de una casa que pertenece a su marido y ha servido de palacio de gobierno desde 1789. Octubre de 1819. Sección Archivo Anexo. Fondo Solicitudes. T. 15, f. 397bisr. AgN, Colombia.

31 María de los Ángeles Ramírez, presa en la cárcel de esta ciudad solicita se le conceda la libertad. 18 de enero de 1813. Sección Archivo Anexo. Fondo Solicitudes. T. 2, f. 697r.-697v. AGN, Colombia.

32 Podría hablarse de la búsqueda de una economía del castigo característica del periodo de independencia, como lo plantea Foucault (2002) para el nacimiento del sistema penal moderno. 
por varias razones: su conducta no había sido criminal, no estuvo entre los que depusieron a las autoridades legítimas; al arribo del jefe revolucionario Simón Bolívar a Honda, su ciudad de residencia, tuvo que huir en precarias condiciones; expuso su vida viajando a Cartagena con el fin de conducir allí a varios europeos para salvarles la vida; de vuelta en Honda solicitó permiso de presentarse en la capital para informar los padecimientos que le había provocado el gobierno insurgente y con la esperanza de recibir recompensa por sus servicios, pero en vez de eso fue conducido a la prisión, donde se mantenía desde hacía dos meses, agravándose allí sus enfermedades porque no era posible administrarle los medicamentos y cuidados que requería. Lozano y Racines agregaban: "no se haga merito de esto y reflexionese que estaba en medio de la fuerza y su vida amenazada por las bayonetas". Terminaban diciendo que no consideraban necesario exponer más razones para justificar su petición, porque confiaban en "la facil penetracion de Vuestra Excelencia que sabe distinguir qual es criminal, y qual inocente". En un documento aparte, Lozano pedía al funcionario encargado que atendiera a "las lagrimas compasivas de una desgraciada muger, consorte, y dos tiernos hijos", y que le permitiera trasladar a su marido a casa, por su "bondad y beneficencia, como por que justamente exerce las reales, paternales y benignidades, del mas Augusto soberano de la tierra". ${ }^{33}$

Los ejemplos presentados anteriormente permiten observar que las características de buen gobierno no se asociaban a un sistema político en particular, sino que esperaban encontrarse en todos ellos. Por eso Rocha y Martínez reclamaban reciprocidad y Caicedo y Lasquetty reclamaban caridad tanto a realistas como a republicanos. Ellas defendieron sus fortunas, sus opiniones y sus derechos tanto en clave monárquica como realista (Lux, 2014, p. 257). Para lograr sus objetivos tuvieron que adaptarse y traducir sus peticiones a los discursos, lenguajes y conceptos manejados por cada gobierno. Por eso para Caicedo serían la equidad y pública confianza en que se basaba el sistema realista las que garantizarían el cubrimiento de su deuda, y para Mendoza lo serían la equidad pero también el atributo liberal del gobierno republicano, cada vez más asociado a los anhelos indepen-

${ }^{33}$ María Josefa Lozano, esposa de Antonio Racines preso en el Colegio del Rosario solicita se le traslade a su casa, bajo fianza. Sección Archivo Anexo. Fondo Solicitudes. T. 6, fs. 207r.-209v. AGN, Colombia.

\section{()(1) $\$$}


dentistas y reconocido como rasgo definitorio del nuevo sistema político (Calderón y Villamizar, 2009, pp. 770-778). Por eso María Ramírez apelaba a la liberalidad del estado de Cundinamarca para procurar su propia libertad y Josefa Lozano al paternalismo del rey para procurar la libertad de su marido. Esta traducción sugiere la existencia de la idea de una especie de gobierno genérico que todo régimen, independientemente de su orientación realista o republicana, debía poner en práctica si quería constituirse como un buen gobierno y evitar el descontento y la oposición de la población. Por otro lado, aunque las mujeres utilizaron la estrategia discursiva del lamento (Lux, 2011, p. 150), no formularon solicitudes en calidad de favores sino de legítimos derechos y, antes bien, llegaron a hacer fuertes críticas y graves acusaciones. Al parecer, el respeto de esos derechos fue más importante a la hora de identificar a los distintos gobiernos como buenos o malos, antes que los proyectos políticos que cada uno proponía. El que las principales preocupaciones de las peticionarias giraran en torno a elementos que ponían en riesgo su vida y su fortuna así como las de sus familiares, asuntos que podrían considerarse más urgentes, cotidianos y materiales, sugiere que su comprensión del entorno político llegó a estar mayormente condicionada por estos últimos que por las propuestas políticas abstractas de las distintas facciones.

\section{LA ADAPTACIÓN ESTRATÉGICA DE LOS DISCURSOS}

Las mujeres demostraron un hábil manejo y adaptación de los discursos, lenguajes y conceptos políticos de acuerdo con sus circunstancias y necesidades. Un caso ilustrativo es el de Magdalena Ortega. Ella y su esposo, Antonio Nariño, formaban parte de las elites santafereñas y asistieron a tertulias que las autoridades virreinales consideraban potencialmente sediciosas, razón por la cual fueron juzgados como traidores (Ramírez, 2010, p. 97). En 1794 Nariño enfrentó cargos por divulgar el documento de los derechos del hombre y el ciudadano y se le acusó de difundir pasquines sediciosos. Sus pleitos con la justicia se prolongaron por 16 años, durante los cuales fue procesado en Santafé, enviado a España, se fugó, volvió a Nueva Granada, se entregó a las autoridades virreinales y, finalmente, fue ence-

\section{()(1) $\$$}


rrado en la ciudad de Cartagena. Con el fin de interceder por su libertad, entre 1795 y 1800 Ortega elevó dos cartas a la reina, una al rey y una al secretario Godoy. En ellas se identificaba como una mujer desamparada que en ausencia de esposo no contaba con recursos para sostener a sus hijos; identificaba a Nariño como un humilde y buen vasallo, un inocente acusado injustamente y mantenido en condiciones inhumanas; señalaba los abusos que los funcionarios virreinales habían cometido al secuestrar sus bienes, negarle el derecho de defenderse y ensañarse contra él por desavenencias personales, y apelaba a la clemencia y cristiandad de los reyes al tiempo que los adulaba. ${ }^{34}$ En junio de 1810 elevó una nueva carta al comisario regio Antonio Villavicencio, quien fue enviado por el Consejo de Regencia, bastión peninsular de apoyo al rey tras la disociación de la Junta Suprema de Sevilla, a negociar la adhesión de las juntas neogranadinas a ese organismo, luego mostró simpatía por el autonomismo, apoyó la independencia y fue fusilado por los realistas en 1816. En su carta Ortega presentaba iguales argumentos, pero posiblemente por su conocimiento de los eventos políticos de España e Hispanoamérica y de las inclinaciones de Villavicencio, se arriesgó a ir más allá en la crítica de las autoridades virreinales, diciendo que el despotismo los tenía sumidos en la infelicidad y ya había empezado a ejercer el terror. ${ }^{35}$

Con la esperanza de que los cambios políticos producidos el 20 de julio de 1810 en la capital favorecieran sus intereses, Ortega envió una última carta a la recién constituida Junta Suprema de Santafé, solicitando que Nariño fuera liberado de la prisión que sufría en Cartagena y le fuera permitido presentarse en la capital para defenderse de los cargos que se le habían imputado. Allí manifestaba que uno de los principios del nuevo gobierno debía ser el asilo a la inocencia perseguida y la religiosa protección de los derechos en que había sido criado el hombre, que debían respetársele al ciudadano para conservar el orden y reciprocidad entre la sociedad y sus miembros, entre la soberanía y el vasallo, entre el magistral y el súbdito. Según ella, los derechos de gentes se oponían a los detestables arbitrios del despotismo de algunos funcionarios, que se consideraban superiores a sus semejantes con

34 Estas cartas se encuentra transcritas en Santos (2010, pp. 69-83).
35 Esta carta se encuentra transcrita en Santos (2010, pp. 106-107).

\section{()(1) $(9$}


el fin de disponer de su hacienda, honor y vida. Debido a ellos, su esposo, noble ciudadano y compatriota honrado, había sufrido una ignominiosa deportación y presidio, y un suplicio desconocido por las leyes de España, rechazado por la recta razón y opuesto a los piadosos sentimientos y preceptos del cristianismo, haciendo con esto referencia a las condiciones lamentables en que se le mantenía en prisión. Identificaba al gobernador del cabildo de Cartagena como el tirano ejecutor de órdenes tan impías, que había pasado por alto la provisión del rey en la que solicitaba información sobre la causa y el procedimiento capcioso de los ministros que la adelantaban. A Nariño no se le había informado el motivo del castigo, ni el juez o tribunal que lo ordenó, simplemente fue arrestado y separado violentamente de su familia y su patria. Ortega se preguntaba "iEn que barbara nacion podia hacerse creible este procedimiento judicial de españoles cristianos? [...] ¿Habrá en el mundo algun codigo que pueda comprehender este orden y clase de juicios? El parece estaba reservado en el corazón de nuestro último extinguido gobierno." Como tal gobierno había sido reemplazado por la Junta, esta tenía que retomar los procesos que aquel había dejado pendientes. Por eso Ortega le manifestaba que ahora "esta Suprema Junta es el Soberano ante quien se debe calificar la justicia de aquella causa y la vindicacion del causado". Adicionalmente, Ortega clamaba con toda la fuerza del derecho natural y divino que se permitiera la vuelta de Nariño y este fuera informado detalladamente de su situación, pues de lo contrario le negarían los medios para defenderse y liberarse de toda opresión. ${ }^{36}$

De los documentos anteriores, llama la atención la manera en que Ortega adaptó el contenido de sus cartas en función del contexto político imperante y de los destinatarios a los que estaban dirigidas. Se puede notar un cambio gradual en su discurso que iba de una indiscutida adhesión a la corona acompañada de una moderada denuncia de los malos manejos de los funcionarios españoles cuando la monarquía aún no había entrado en crisis, pasando por una fuerte crítica de las instituciones virreinales a las que identificaba con el despotismo y el terror cuando el Consejo de Regencia

36 Doña Magdalena Ortega, esposa de Antonio Nariño, escribe a la Suprema Junta; describe el padecimiento de su esposo, preso en Cartagena. 31 de agosto de 1810. Sección Archivo Anexo. Fondo Historia. T. 11, fs. 79r.-80v. AGN, Colombia.

\section{()(1) $(9$}


intentaba mantener con dificultad un foco legítimo de apoyo al rey, y terminaba cuestionando a la misma España y reconociendo a la Junta de Gobierno como el nuevo soberano poco después de que esta había socavado el poder virreinal y se había constituido como la nueva cabeza del poder político. De su última carta es notorio cómo logró recoger los principales debates políticos que se estaban presentando en Santafé en ese momento. Cuando hablaba de los derechos en que había sido criado el hombre y que debían respetársele al ciudadano, parecía hacer una clara referencia a los derechos del hombre y del ciudadano que su esposo había traducido años atrás. Cuando decía que ese respeto aseguraba la conservación del orden y la reciprocidad, parecía sugerir que España no había cumplido con las obligaciones recíprocas que tenía con sus vasallos y por eso había sido necesario el establecimiento de la Junta y el derrocamiento del poder virreinal. Insinuaba que España no sólo había quebrantado los derechos del hombre y el ciudadano, sino también sus propias leyes, el derecho de gentes, el derecho natural y el derecho divino, al tolerar los desmanes de sus funcionarios y la crueldad de sus procedimientos judiciales. Insinuaba que el gobierno español se había acercado a la barbarie y la irracionalidad y se había alejado de los principios cristianos que formaban parte del discurso legitimador monárquico, a semejanza del incitador Memorial de agravios escrito en 1809 por el abogado neogranadino Camilo Torres como respuesta a la escasa representación americana convocada por la Junta Suprema de Sevilla, donde se calificaba al despotismo de bárbara crueldad enemiga de Dios, que sólo aspiraba a mantener a los hombres como manadas de siervos viles destinados a satisfacer sus ambiciones (Torres, 1960, p. 8). Su reflexión parecía justificar no sólo la formación de la Junta de Santafé que desafió a las autoridades virreinales, sino también los actos de su esposo que fueron considerados sediciosos en su momento.

Sin embargo, según su disertación no habían sido el rey ni el sistema monárquico en su totalidad los que habían cometido la falta, sino los funcionarios corruptos que, considerándose superiores a los demás, intentaban quedarse con sus haciendas y sus vidas. Parecía referirse a los funcionarios españoles con los que se mantenían en constante tensión las elites criollas de las que Ortega formaba parte, porque aquellos les ganaban los cargos públicos, representaban la tiranía y el despotismo burocrático, se dudaba de su capacidad para responder a un potencial ataque de los franceses e incluso se sospechaba de su colaboración con los mismos. Ortega parecía adherir a la

\section{()(1) $(9$}


consigna de "Viva el rey, muera el mal gobierno", tradición de larga data que cuestionaba el manejo de los funcionarios sin cuestionar necesariamente la autoridad del rey, y utilizado en el Nuevo Reino de Granada durante la llamada revolución de los comuneros de 1781 (Phelan, 2009, p. 15) y al parecer rescatado bajo otros términos para el tiempo de la independencia, que respondía a la inconformidad con las autoridades virreinales, pero que aún no manifestaba intenciones separatistas. Al reconocer a la Junta como el nuevo soberano a quien correspondía decidir la causa de su marido, Ortega también parecía adherir al acta de la Junta que declaraba que no abdicaría "los derechos imprescriptibles de la soberanía del pueblo a otra persona que a la de su augusto y desgraciado monarca don Fernando VII, siempre que venga a reinar entre nosotros" (Quintero y Martínez, 2007, p. 8). Cabe preguntarse si al insistir en que Nariño fuera juzgado en Santafé (no en España, cuya autoridad sobre las juntas americanas estaba en entredicho, ni en Cartagena, que tenía su propia junta) no estaría apelando a las pretensiones autonomistas tan en boga en ese momento entre numerosas provincias, ciudades y villas, que al defender su propia soberanía defendieron al mismo tiempo su autonomía por encima de antiguas jerarquías jurisdiccionales y territoriales emanadas del gobierno monárquico, fenómeno que Catalina Reyes (2010, p. 41) ha llamado "explosión de múltiples soberanías locales" e Isabel Restrepo (2005, pp. 101) "multiplicación territorial de la soberanía”. Por último, cuando manifestaba que si no se permitía a Nariño regresar se le estarían negando los medios para defenderse y liberarse de toda opresión, posiblemente intentaba precaver a la Junta de que si no procedía en los términos que demandaba, no sólo evitaría que su marido se librara de la opresión de los españoles, sino que ella misma se constituiría como agente de opresión, dando pie a que los vasallos o ciudadanos se levantaran contra ella.

El de Ortega no es necesariamente un caso representativo de todas las mujeres, pues sus circunstancias eran muy diferentes a las de otras: pertenecía a las elites criollas, gran parte de las cuales habían estado comprometidas con la lucha por la independencia, había recibido una buena educación y había formado parte de círculos ilustrados, todo lo cual se traslució en su prosa. Hubo mujeres partidarias del realismo que fueron capaces del mismo nivel de argumentación. Es ilustrativo el caso de la venezolana María Antonia Bolívar, quien desde un principio rechazó la causa independentista, aun en contra de sus hermanos, entre los cuales se encontraba el propio Simón

\section{()(1) $(3$}


Bolívar. Esta mujer, que formaba parte de la aristocracia mantuana, vio en la revolución de independencia la lamentable alteración del orden legítimo que por generaciones le había asegurado a ella y a los de su clase una posición predominante en la sociedad. Por eso se manifestó abiertamente realista, ayudó a españoles y realistas perseguidos por las fuerzas republicanas y ella misma fue víctima de la represión (Quintero, 2005). Para Nueva Granada destaca el caso de Bonifacia Ayala, viuda de un militar a órdenes del gobierno virreinal de nombre Francisco Fernández, quien señalaba que su esposo había desempeñado su cargo con total honradez, hasta que había acaecido la fatal, desgraciada y detestable revolución del 20 de julio (la misma que había desembocado en la formación de la junta a la que Magdalena Ortega reconocía como el nuevo soberano). Ayala añadía que Fernández había rechazado un cargo que le había ofrecido el gobierno revolucionario, pues "primero quiso entregarse a manos de la muerte que en los del servicio de semejante gobierno", y de hecho había muerto en 1814 "agobiado con el peso de la persecución de los insurgentes contra los españoles, y no teniendo que dejar a su familia al tiempo de morir, nos dejo a mí, y a mi pequeño hijo la esperanza de que algún día volvería vuestra majestad a reinar en estos dominios, y que entonces experimentaríamos la real clemencia". ${ }^{37}$ Las peticiones tanto de Ortega como de Ayala, con lo extenso de su prosa, lo profundo de sus reflexiones, lo pulido y ornamentado de su lenguaje, contrastaban notablemente con las peticiones de otras mujeres que no compartían un lenguaje tan refinado. Por ejemplo, la petición de Francisca Pérez no ocupaba más de una página y utilizaba una redacción bastante sencilla e incluso descuidada. Sin embargo, eso no le impidió exponer hechos y opiniones con tintes políticos. Ella pedía a las autoridades republicanas la liberación de su esposo, quien "si erró en alguna cosa ya estará bueno el castigo pues soy una pobre cargada de familia". Aclaraba que ambos habían huido por los montes a causa de haber sido fieles a la patria. Era "prueba de ello que anochecía aquí entre los godos [apelativo que se daba a los españoles] expuesto a que lo mataran como que ofrecían dinero al que lo cogiese; y amanecía llegando a Chocontá con armas, gente y pertrechos adonde dicho ciudadano Almeyra

${ }^{37}$ María Bonifacia Ayala, viuda de Francisco Fernández solicita le abonen los sueldos que le adeudan a este como guarda que fue de la Ronda Volante de esta capital. 1818 y 1819. Sección Archivo Anexo. Fondo Solicitudes. T. 12, fs. 580r.-594v. AGN, Colombia.

\section{()(1) $\$$}


[reconocido revolucionario]" ${ }^{38}$ Difiere de esta petición la que en 1816 elevó María Belber a las autoridades realistas, la cual estaba redactada de manera bastante clara pero también bastante corta y sencilla, y no contenía ninguna referencia a la situación política del momento. Belber se limitaba a solicitar que se le pagaran los meses atrasados de su pensión, pues era una pobre viuda de familia numerosa que no tenía más de que subsistir que el corto trabajo de sus manos. ${ }^{39}$ Las mujeres usaron adecuadamente fórmulas retóricas con que las autoridades se identificaban a sí mismas y a sus enemigos, para congraciarse con ellas pero también para evitar las represalias que pudiera generar el uso desacertado de un concepto o discurso. Ejemplo de ello es la categoría "ciudadano". Como se mencionó anteriormente, de 36 mujeres que se dirigieron a las autoridades del primero y segundo periodo republicano, 16 dieron el apelativo de ciudadano a uno o varios individuos, catorce se presentaron a sí mismas como ciudadanas y diez de las mismas fueron designadas como ciudadanas por parte de los mismos funcionarios que recibían y tramitaban sus peticiones. Varias autoras han trabajado el tema de la ciudadanía femenina durante el periodo independentista y republicano en Latinoamérica (Chambers, 2004; Díaz, 2004; Pani, 2006). Allí observan que el ciudadano estaba pensado como hombre, padre de familia, mayor de edad, con propiedad y trabajo independiente, excluyendo de la ciudadanía a otros grupos de hombres, $\mathrm{y}$ a todas las mujeres en función de su género. Hubo fuertes resistencias a conceder la ciudadanía femenina y en ocasiones esa posibilidad ni siquiera se discutió, pues las mujeres eran consideradas seres domésticos, ajenos a los asuntos políticos, incapacitadas para actividades productivas y militares, y representados a través de los hombres de su familia. De ellas se esperaba que engendraran a los nuevos ciudadanos y les inculcaran el amor a la patria. Pero la definición misma de ciudadanía fue un objeto de disputa que adquirió significados diferentes dependiendo desde que sector social se enfocaba, engendrando desajustes y ambigüedades. Existió la probabilidad de que ellas

${ }^{38}$ Francisca Pérez, mujer legítima de Roque Ayure quien se encuentra preso, solicita para este la libertad. 6 de diciembre de 1819. Sección Archivo Anexo. Fondo Solicitudes. T. 15, f. 507r. AGN, Colombia.

${ }^{39}$ Expediente sobre el reclamo que adelanta María del Pilar Belber, viuda del administrador de tabacos de Valledupar Juan Fernández de Ugarte, con el fin de que se le paguen los meses atrasados de la pensión que le fue concedida por el rey desde 1809. Diciembre de 1816. Sección Archivo Anexo. Fondo Solicitudes. T. 21, fs. 293r.-294r. AGN, Colombia.

\section{()(1) $(9$}


desearan obtener lo mismo que los hombres y alcanzar la igualdad con ellos. La caracterización abstracta y universal de la ciudadanía en ocasiones permitió que las mujeres se sintieran incluidas en ella y reclamaran el estatus y derechos que consideraban que la república les adeudaba, abriendo la posibilidad a una vertiente femenina de la ciudadanía, aun cuando fuera considerara inferior a la masculina. Para el caso de Nueva Granada el tema de la ciudadanía femenina ha sido abordado por Martha Lux (2014, pp. 153-214). Ella señala que durante los periodos republicanos la ciudadanía permaneció indefinida. Esa indefinición, promovida deliberadamente por las elites para evitar la división interna, permitió que distintos sectores de la sociedad contemplaran la posibilidad de acceder al estatus de ciudadanos y a los privilegios que este conllevaba, entre ellos las mujeres. En Nueva Granada también hubo fuerte oposición a la concesión de la ciudadanía femenina, o ni siquiera se pensó en esa posibilidad por suponer que ellas quedaban representadas a través de sus padres y esposos. Eso no impidió a las autoridades apelar a su patriotismo y convocarlas a defender la causa como ciudadanas. Las mujeres respondieron al llamado, se sintieron incluidas en la nación, se presentaron a sí mismas como ciudadanas, esperaron ser cobijadas por las prerrogativas de la ciudadanía y en nombre de esa identificación reclamaron los que consideraban sus derechos.

Aunque en un principio "ciudadano" no tenía connotaciones políticas más allá del ejercicio de cargos públicos a nivel local, después de 1808 empezó a adquirir matices autonomistas, actuar como elemento integrador alrededor de nuevos valores políticos como el patriotismo, identificarse con el establecimiento de un nuevo sistema político como lo era el Estado, y dar prestigio a quien se reconocía como tal (König, 2009, pp. 234-240). Dada la carga simbólica de este término, el uso que se hizo de él en las peticiones para designar a las mujeres no parece inocente, sino que sugiere reflexiones y transformaciones que se estaban dando alrededor de su presencia y su estatus dentro del nuevo sistema político. En todo caso, aunque las reconocieran de palabra como ciudadanas, no parece que las autoridades tuvieran la intención de concederles los mismos derechos que a los ciudadanos hombres. Por su parte, es posible que las peticionarias santafereñas que se presentaron a sí mismas como ciudadanas no necesariamente esperaran acceder a una ciudadanía plena. Aparte de su autodenominación como tales, en sus peticiones el tema de la ciudadanía no se vuelve a mencionar; no reclaman

\section{()(1) $\$$}


la adquisición de derechos ciudadanos, sino más bien el respeto de ciertas prerrogativas mucho más generales, que podrían haberse exigido incluso al gobierno monárquico, como por ejemplo la realización de juicios justos o el respeto a los bienes particulares. En cambio, utilizaron muchos discursos de género que resaltan su maternidad y domesticidad, así como la debilidad, desamparo y dependencia que se suponían inherentes a ellas. Para las autoridades llamar a las mujeres ciudadanas pudo haber representado una manera de ganar su apoyo para la causa, e imponerles ciertos deberes para con el Estado que no habrían podido quedar justificados de no reconocerles un estatus ciudadano al menos de carácter nominal. Para las mujeres autoidentificarse como ciudadanas pudo haber sido una manera de reclamar la posibilidad de la ciudadanía para sí, aun cuando no fuera una ciudadanía plena, definida bajo parámetros masculinos. Al mismo tiempo, pudo haber sido una manera de demostrar su compromiso y adhesión a la causa independentista para congraciarse con las autoridades republicanas, y así poder negociar sus demandas desde una posición más ventajosa. Si tanto las mujeres como quienes asesoraron sus peticiones hubieran sospechado que la designación de ciudadanas causaría algún tipo de malestar en las instancias gubernamentales y obstaculizaría el curso de sus demandas, lo más probable es que no la hubieran utilizado. El que se resolvieran a hacerlo, así como el que algunos de los funcionarios que tramitaron las peticiones también se refirieran a ellas como ciudadanas, sugiere no sólo que había cierto grado de tolerancia a esta forma femenina de nombrar, sino incluso que ciudadana pudo haberse convertido en una más de las fórmulas retóricas comunes en las instancias y papeles oficiales. Fuera como fuera, el solo hecho de utilizar este apelativo introducía a quienes lo hacían en las disputa por el significado de la ciudadanía. En este punto, vale la pena preguntarse también por aquellas mujeres que no se presentaron como ciudadanas aunque también se dirigían al gobierno republicano; si acaso aquello denotaba rechazo o indiferencia frente al nuevo sistema político, si acaso expresaba incredulidad ante la posibilidad de acceder a una ciudadanía que continuaba vedada incluso para la mayoría de la población masculina, o si simplemente se debía a que seguía los modelos acostumbrados antes de la popularización del apelativo de ciudadano. De todas formas, el resistirse al uso de esta denominación no parece que haya traído consecuencias negativas para las peticionarias. Esto suena lógico si recordamos que el ideal femenino se había transformado muy

\section{(ㅇ)(1) $\$$}


poco, y en principio las mujeres seguían siendo vistas como seres apolíticos e incapacitados para la ciudadanía.

Las mujeres que se dirigieron a las autoridades republicanas hablaron en términos propios de estas, usando las jerarquías, conceptos e ideas que promovían. Buen ejemplo de ello es Mariana Hurtado, quien dirigía su carta al presidente supremo de la república, se presentaba como ciudadana, esposa del ciudadano Antonio Niño, para quien pedía libertad de la prisión. Ella narraba que tras la acción del ejército libertador contra el ejército opresor de los españoles en el pueblo de Leyva, estos últimos habían regresado al pueblo de Labranzagrande, donde ella y su esposo residían, y habían hostilizado y amenazado a quienes se habían resistido a emigrar. Por esa razón ella y Niño se habían retirado al pueblo de Monguí. Cuando su esposo supo que las tropas libertadoras se hallaban en Sogamoso se presentó allí para alistarse en ellas y se le dio un pasaporte para que regresara a Labranzagrande a recaudar y remitirles lo correspondiente a los diezmos. Sin embargo, al llegar a su destino fue encarcelado por un funcionario que le profesaba mala voluntad, y le fueron embargados los pocos haberes que la codicia de los españoles le había dejado. Por eso Hurtado apelaba al liberal y piadoso amparo del presidente, cuyo benigno brazo los había sacado de la opresión y cuya heroicidad había sido en obsequio de la libertad. ${ }^{40}$ De manera similar, Juana Plazas pedía a las autoridades republicanas que se le permitiera a su marido, Apolinar Chaparro, licenciarse del ejército y se le concediera la administración de unas alcabalas, en atención a sus grandes pérdidas y padecimientos. Plazas refería que "llegó a comprender el sátrapa [jefe realista] Lucas Gonzáles agente de la tiranía en Tunja, que Chaparro se comunicaba con los patriotas del Llano, que detestaba el ignominioso yugo español y meditaba su exterminio. Por eso no habiendo logrado su captura, circuló orden para que donde quiera se le hallase fuera pasado a cuchillo con su mujer e hijos", y le fueron secuestrados todos los bienes. ${ }^{41}$ Por su parte, María Alvina Figueredo aseguraba

40 Mariana Hurtado, esposa legítima de Antonio Niño, quien se encuentra arrestado por orden del coronel Juan José Molina, solicita se le conceda a este la libertad. 29 de agosto de 1819. Sección Archivo Anexo. Fondo Solicitudes. T. 15, f. 256bisr.-256bisv. AgN, Colombia.

${ }^{41}$ Comunicaciones enviadas por Juana Plazas al gobernador de la provincia de Cundinamarca, el general Francisco de Paula Santander. Sección Archivo Anexo. Fondo Solicitudes. T. 12, f. 585r. AGN, Colombia.

\section{()(1) $(9$}


que desde que a su esposo "se lo llevaron los infames españoles en la retirada que han hecho y lo han matado en Guaduas me he quedado huérfana y desamparada". ${ }^{42}$ Los apelativos con que estas mujeres caracterizaban a los realistas y a los patriotas son prácticamente los mismos que figuran en los discursos y proclamas del general republicano Simón Bolívar. A los primeros este los entendía como españoles opresores, tiranos, infames y codiciosos; a los segundos como libertadores, héroes y defensores de la libertad y la liberalidad. Bolívar también expresó el conflicto en términos nacionalistas, si no entre dos naciones como tal, sí entre dos territorios y dos orígenes distintos: el español y el americano (Blanco, 2007, pp. 41-301). ${ }^{43}$ Expresiones parecidas se encuentran en la petición de Candelaria Cantillo, quien en 1815 reclamaba a las autoridades republicanas el encarcelamiento de su marido únicamente porque era de origen español: "que no se diga señor que en la Nueva Granada se mira como un crimen el servicio de los españoles, que su adhesión a la causa americana es un delito" ${ }^{44}$ Las peticionarias también parecieron retomar elementos de la leyenda negra española que relacionaba la península con la cristianización violenta, el saqueo ilimitado de recursos, la opresión del pueblo indígena, la corrupción, la codicia, el despotismo, la tiranía, la irracionalidad y la barbarie; leyenda que venía de la retórica antihispana producida en el contexto de las guerras por la religión de los siglos XVi y XVII (García-Caro, 2011, pp. 43-49), se retomó para criticar las políticas borbónicas y pareció cobrar renovado ímpetu durante la independencia, cuando España pasó de ser la madre patria a ser una "desnaturalizada madrastra". ${ }^{45}$

Por su parte, las mujeres que dirigieron sus peticiones a las autoridades realistas no osaron hacer ninguna referencia a la ciudadanía. Durante el tiempo que duró la reconquista del territorio neogranadino por parte de las

${ }^{42}$ Marái Albina Figuredo, solicita el pago o devolución de algunas cosas que dejó su difunto esposo Juan José Roa. 26 de agosto de 1819. Sección Archivo Anexo. Fondo Solicitudes. T. 15, f. 273bisr. AGN, Colombia.

${ }^{43}$ Sobre el significado de los conceptos español-americano y español-europeo véase Lomné (2009, pp. 101-115).

${ }^{44}$ Candelaria Cantillo, esposa de Domingo Viña solicita para este la libertad, bajo fianza que ofrece José Diago. 1815. Sección Archivo Anexo. Fondo Solicitudes. T. 4, f. 306v. AGN, Colombia.

${ }^{45}$ Así fue llamada por Simón Bolívar en su famosa Carta de Jamaica y por otros críticos del régimen monárquico. Véase Gutiérrez (2010, p. 256); Penagos (2012, p. 39).

\section{()(1) $(9$}


fuerzas reales, "ciudadano" fue considerado un apelativo odioso, deformado hasta el punto de asimilarse al desorden y la rebelión, a los rebeldes, los insurgentes y los revolucionarios (König, 2009, pp. 234-240). En este periodo la población dejó de autodenominarse y denominar a otros como ciudadanos, pues hacerlo podía poner en riesgo sus vidas (Serrano, 2014, pp. 160-168). Las mujeres hablaron en términos del pacto entre el rey y sus vasallos, donde el primero era representante de dios en la tierra, y figuraba como un padre que daba protección, aseguraba la conservación del orden y actuaba con justicia y compasión. Los segundos figuraban como hijos que debían guardar amor, obediencia y lealtad a su rey (Gil, 2009). Así, cuando Francisca Pey solicitó un indulto para su hermano, señaló que este siempre había sido respetuoso y obediente y jamás había perdido la adhesión y fidelidad debida al soberano, al tiempo que recordaba que el rey ya había tenido ese mismo gesto bondadoso con otros individuos que habían sido indultados. ${ }^{46}$ Josefa Fierro, al pedir la libertad de su hijo, argumentaba que "jamás se le ha oído una sola expresión que se oponga a los deberes de un buen vasallo de nuestro amado monarca", y en cuanto al funcionario destinatario de su petición, apelaba "a la generosidad y benignidad de sus sentimientos, y a que estos se oponen a los sufrimientos del infeliz que padece inocente" ${ }^{47}$ Por su parte, cabe recordar a la ya mencionada Josefa Lozano, quien cuando solicitaba a un funcionario la liberación de su esposo, apelaba a su "bondad y beneficencia, como por que justamente exerce las reales, paternales y benignidades, del mas Augusto soberano de la tierra" ${ }^{48}$

$\mathrm{Al}$ dirigirse al gobierno realista las mujeres también entendieron a este como el legítimo. Así lo evidencia Bonifacia Ayala cuando decía que su esposo, antes de morir, le había dejado la esperanza de "que a la vuelta del gobierno legítimo experimentaría las bondades del rey". Ayala también re-

${ }^{46}$ Francisca Pey, representa por su legítimo hermano el doctor Juan Bautista, arcediano de la iglesia metropolitana. Agosto de 1817. Sección Archivo Anexo. Fondo Solicitudes. T. 10, f. 35r.-35v. AGN, Colombia.

${ }^{47}$ Josefa Fierro, solicita le concedan la libertad a su hijo Jerónimo, quien se encuentra preso en el cuartel del tambo. Septiembre de 1817. Sección Archivo Anexo. Fondo Solicitudes. T. 10, f. 197r. AGN, Colombia.

${ }^{48}$ María Josefa Lozano, esposa de Antonio Racines preso en el Colegio del Rosario solicita se le traslade a su casa, bajo fianza. Sección Archivo Anexo. Fondo Solicitudes. T. 6, f. 208v. AGN, Colombia.

\section{()(1) $\$$}


saltaba el carácter católico del rey cuando despedía sus peticiones pidiendo que "nuestro señor guarde la católica real persona de vuestra majestad". ${ }^{49}$ Por su parte, cuando Isabel Caicedo solicitaba a un funcionario realista la devolución de su dote, apelaba a la humanidad, generosidad y cristiandad del mismo, parecía estar relacionando al sistema monárquico con la práctica de la religión cristiana. ${ }^{50} \mathrm{Al}$ sistema republicano, en cambio, lo entendieron como ilegítimo, y mostraron oposición y repugnancia frente a la revolución y a los jefes revolucionarios, a los que entendían como perturbadores del orden y perpetradores de la delincuencia. Por ejemplo, Josefa Lozano y Concepción Racines calificaban al gobierno republicano de revolucionario, ilegítimo e insurgente, y llamaban sanguinario a Simón Bolívar. ${ }^{51}$ Felipa Tello, al solicitar la liberación de su esposo, argumentaba que este se había mantenido retirado en su casa "hasta el tiempo de las conmociones, suscitadas por algunos criminales, que procuraban evadirse de los castigos que merecían por sus excesos". Añadía que para alejarse de las tropelías de aquellos él y su familia habían tenido que refugiarse en una hacienda, de donde se lo llevaron las tropas realistas por pensar que formaba parte de los insurgentes. ${ }^{52}$ Josefa Santa Cruz, quien solicitaba que se le concediera un montepío, relataba que su marido "después de haber servido en las armas del rey nuestro señor, con el mayor crédito y desempeño en las funestas revoluciones falleció habiendo sido herido de muerte en el campo de Cebollas por las tropas del pérfido Nariño"53 (se refería Antonio Nariño, esposo de Magdalena Ortega). Vale la

49 María Bonifacia Ayala, viuda de Francisco Fernández solicita le abonen los sueldos que le adeudan a este como guarda que fue de la Ronda Volante de esta capital. 1818 y 1819. Sección Archivo Anexo. Fondo Solicitudes. T. 12, f. 593r. AgN, Colombia.

${ }^{50}$ Colombia. Isabel Caicedo, vecina de esta capital expone sobre su extrema pobreza y solicita alguna ayuda. Abril de 1818. Sección Archivo Anexo. Fondo Solicitudes. T. 11, f. 678r. AGN, Colombia.

${ }^{51}$ Lozano María Josefa, esposa de Antonio Racines preso en el Colegio del Rosario solicita se le traslade a su casa, bajo fianza. Sección Archivo Anexo. Fondo Solicitudes. T. 6, fs. 207v.-209r. AGN, Colombia.

${ }^{52}$ Felipa Tello, solicita le concedan la libertad a su esposo Rito Acosta, quien se halla preso en cuartel de Numancia. 23 de diciembre de 1817. Sección Archivo Anexo. Fondo Solicitudes. T. 10, f. 641r. AGN, Colombia.

${ }^{53}$ Josefa Santa Cruz, vecina de Pasto viuda de Juan María de la Villota solicita se le declare el montepío que le corresponde por los servicios prestados por su esposo. 28 de mayo de 1818. Sección Archivo Anexo. Fondo Solicitudes. T. 3, f. 551r. AGN, Colombia.

\section{()(1) $\$$}


pena recordar también la calificación de fatal, desgraciada y detestable que Bonifacia Ayala daba a la revolución del 20 de julio. ${ }^{54}$ Las expresiones de las mujeres mostradas anteriormente se asemejan a aquellas con que se expresaron las autoridades realistas de los republicanos en distintos momentos. Así lo evidencia el impreso que en 1816 el gobierno realista dirigió a los alcaldes y curas de los pueblos vecinos a Santafé, pidiéndoles que vigilaran a las familias que llegarían allí tras ser desterradas de la capital por haber participado en los hechos del 20 de julio, la mayoría de ellas encabezadas por mujeres. En el impreso se decía que "la corrupción de costumbres, y la vida licenciosa y perversa que los innovadores turbulentos y desleales, después de trastornar el orden, establecieron para alcanzar sus detestables ideas bajo el velo de la libertad, produjo en todas las clases del estado los más pernicioso ejemplos". Se añadía que "de aquí la irreligión y el escándalo con que se hallaban las máximas sagradas del evangelio. Al paso que este mal corrió a derribar los altares, ningunos han sido más infestados de él que las familias y los hijos de estos mismos traidores que tan abiertamente hacían gala de su depravación". Se encargaba a los mencionados funcionarios eclesiásticos y políticos que mantuvieran una escrupulosa vigilancia sobre los desterrados "por ser todo tan interesante al servicio de Dios y del Rey". ${ }^{55}$

Un caso que ilustra la gran capacidad de adaptación estratégica de las mujeres a los lenguajes utilizados por los distintos gobiernos según la orientación política de cada uno es, una vez más, el de Isabel Caicedo. Cuando en 1818 se dirigió a las autoridades realistas para pedir la devolución de su dote confiscada dentro de los bienes de su marido Antonio Baraya, condenado a muerte por insurgente, manifestó que los desgraciados delirios del tiempo de la revolución le habían trastornado la cabeza pero que ojalá siempre hubiera permanecido al servicio del comandante realista Juan Sámano, bajo cuyo

${ }^{54}$ María Bonifacia Ayala, viuda de Francisco Fernández solicita le abonen los sueldos que le adeudan a este como guarda que fue de la Ronda Volante de esta capital. 1818 y 1819. Sección Archivo Anexo. Fondo Solicitudes. T. 12, fs. 580r.-594v. AgN, Colombia.

${ }^{55}$ Impreso dirigido a los curas y alcalde de Santafé en donde se le indician las instrucciones de cómo manejar a las familias y en especial mujeres y niños de aquellos simpatizantes de la revolución, recalcándoles la enseñanza dentro de la doctrina católica y la austeridad en su forma de comer y vestir. 12 de enero de 1816. Sección Archivo Anexo. Sección Historia. T. 20, f. 146r.-146v., Fondo Solicitudes. T. 12, fs. 580r.-594v. AGN, Colombia.

\section{()(1) $\$$}


servicio se desempeñaba antes de la formación de la Junta de $1810 .{ }^{56}$ Cuando, un año más tarde, se dirigió a las autoridades republicanas que recientemente habían expulsado a los realistas y habían asumido el poder en Santafé, Caicedo se presentaba a sí misma y a su esposo como ciudadanos y resaltaba la jerarquía militar que este último había obtenido en el servicio que prestó a la primera república neogranadina. ${ }^{57}$

\section{CONCLUSIONES}

Este trabajo rastrea la comprensión que tuvieron las mujeres de su entorno político a partir de su conciencia política, definida como la forma que dieron a la cultura política a través de los usos particulares de lenguajes y conceptos políticos a su disposición, expresada en la interacción que mantuvieron por medio de peticiones con las autoridades republicanas y realistas que alternaron entre 1810 y 1820 en Nueva Granada. La conciencia política se manifestó en tres temas principales. El primero fue la compleja definición de la conducta política que incluía componentes de índole moral, laboral, de edad, género y estratificación social, etc., y sugería una visión integral del individuo en la que si este se comportaba correctamente en el ámbito político se esperaba que también lo hiciera en los demás ámbitos de su vida. Esto, en vez de llevar a despolitizar la conducta política, invita a complejizar el significado que se daba a la política en ese momento, pensando los componentes mencionados no como condicionantes sino como constitutivos de la misma. El segundo giró alrededor del comportamiento correcto o incorrecto de las autoridades, enfocado en la reciprocidad del gobierno con la fidelidad y servicios de sus gobernados, el trato preferente con los más necesitados, el respeto de los bienes particulares y la recta administración de justicia penal. Estas prerrogativas no se asociaron a un gobierno en particular sino que se

${ }^{56}$ Isabel Caicedo, vecina de esta capital expone sobre su extrema pobreza y solicita alguna ayuda. Abril de 1818. Sección Archivo Anexo. Fondo Solicitudes. T. 11, fs. 677bisr.-678v. AGN, Colombia.

${ }^{57}$ Comunicación enviada por Isabel Caicedo, viuda del general Antonio Baraya, fusilado por el general Pablo Morillo, quien fue despojada de todos y cada uno de los bienes dejándola en la absoluta miseria. 2 de octubre de 1819. Sección Archivo Anexo. Fondo Historia. T. 26, f. 717r.-717v. AGN, Colombia.

\section{()(1) $\$$}


esperaron de todos ellos y para reclamarlas se tradujeron a los discursos, lenguajes y conceptos políticos que manejaba cada uno. Lo anterior sugiere la idea de una especie de gobierno genérico que todo régimen debía poner en práctica si quería constituirse como buen gobierno y evitar descontentos y oposición de la población. El cumplimiento de tales prerrogativas, exigidas en calidad de derechos, condicionó la identificación de los gobiernos como buenos o malos aun más que los proyectos políticos de cada uno. Por otro lado, el que las principales preocupaciones de las mujeres tuvieran que ver con asuntos urgentes, cotidianos y materiales sugiere que estos fueron mayores condicionantes de la comprensión del entorno político que las propuestas políticas abstractas de las facciones. El tercero remite al hábil manejo que las mujeres hicieron de los discursos, conceptos y lenguajes políticos según el contexto político imperante, las autoridades destinatarias y sus propias necesidades e intereses.

\section{LISTA DE REFERENCIAS}

Arrom, S. (1998). Las mujeres de la ciudad de México 1790-1857. México: Siglo XXI Editores.

Bermúdez Escobar, I. (2001). Imágenes y representaciones de la mujer en la Gobernación de Popayán. Quito: Universidad Andina Simón Bolívar/Corporación Editora Nacional.

Bermúdez, S. (1995). Familia y hogares en Colombia durante el siglo xix y comienzos del xx. En M. Velásquez (dir.), Las mujeres en la historia de Colombia (t. 2, pp. 240-291). Santafé de Bogotá: Consejería Presidencial para la Política Social/Editorial Norma.

Bernal, B. (1989). Las características del derecho indiano. Historia Mexicana, 38(4), 663-675. Recuperado de: http://codex.colmex.mx:8991/exlibris/aleph/a18_1/apa che_media/SK3VRSQKL7L18E9RNRE54N1CJ84TIK.pdf

Blanco, R. (2007). Discursos y proclamas. Simón Bolivar. Caracas: Fundación Biblioteca Ayacucho.

Botero, N. (julio-diciembre, 2012). El problema de los excluidos. Las leyes contra la vagancia en Colombia durante las décadas de 1820 a 1840. Anuario Colombiano de Historia Social y de la Cultura, 39(2), 41-68. Recuperado de: http://www.revistas. unal.edu.co/index.php/achsc/article/view/37472/39826

\section{()(1) $\$$}


Brewster, C. (2005). Women and the Spanish-American wars of independence: an overview. Feminist Review, 79, 20-35. Recuperado de: http://link.springer.com/ar ticle/10.1057/palgrave.fr.9400200\#page-1

Calderón, M. T. y Villamizar, C. (2009). Liberalismo. Colombia. En J. Fernández (dir.), Diccionario político y social del mundo iberoamericano. La era de las revoluciones, 1750-1850 (pp. 770-782). Madrid: Fundación Carolina/Sociedad Estatal de Conmemoraciones Culturales/Centro de Estudios Políticos.

Chambers, S. (2004). De súbditos a ciudadanos: honor, género y política en Arequipa, 17801854. Lima: Red de Ciencias Sociales.

Cherpak, E. (1995). Las mujeres en la independencia. Sus acciones y contribuciones. En M. Velásquez (dir.), Las mujeres en la historia de Colombia (t. 1, pp. 83-116). Santafé de Bogotá: Consejería Presidencial para la Política Social/Editorial Norma.

Condés, M. T. (2002). Capacidad jurídica de la mujer en el derecho indiano. (Tesis de doctorado inédita). Universidad Complutense de Madrid, Madrid.

Díaz, A. (2004). Female citizans, patriarchs, and the law in Venezuela, 1786-1904. Lincoln: University of Nebraska Press.

Dougnac, A. (1994). Manual de historia del derecho indiano. México: Universidad Nacional Autónoma de México.

Falcón, R. (2006). El arte de la petición: rituales de obediencia y negociación, México, segunda mitad del siglo xIx. Hispanic American Historical Review, 86(3), 467-500. DOI: 10.1215/00182168-2006-002.

Fernández, J. (2009). Introducción. En J. Fernández (dir.), Diccionario político y social del mundo iberoamericano. La era de las revoluciones, 1750-1850 (pp. 25-45). Madrid: Fundación Carolina/Sociedad Estatal de Conmemoraciones Culturales/Centro de Estudios Políticos y Constitucionales.

Foucault, M. (2002). Vigilar y castigar. Nacimiento de la prisión. Buenos Aires: Siglo XXI Editores.

Garrido, M. (1993). Reclamos y representaciones. Variaciones sobre la política en el Nuevo Reino de Granada, 1770-1815. Santafé de Bogotá: Banco de la República.

Garrido Asperó, M. J. (2013). La participación política de las mujeres en México, 18101823. La Gaceta Política, 10(1), 61-71. Recuperado de: https://issuu.com/gacetacpol/ docs/gaceta_ciencia_poli_tica_primavera_verano_2013

García-Caro, P. (2011). Las minas del rey Fernando: plata, oro, y la barbarie española en la retórica independentista hispanoamericana. Anales de Literatura Hispanoamericana, 40, 39-59. DoI: http://dx.doi.org/10.5209/rev_ALHI.2011.v40.37311

\section{()(1) $(3$}


Gil, X. (2009). The good law of a vassal: fidelity, obedience and obligation in Habsburg Spain. Revista Internacional de Estudios Vascos, 5, 83-106. Recuperado de: http://hedatuz.euskomedia.org/7580/1/05083106.pdf

González, C. (2012). El abogado y el procurador de pobres: la representación de esclavos y esclavas a finales y principios de la república. SudHistoria, 5, 81-98. Recuperado de: https://dialnet.unirioja.es/servlet/articulo?codigo $=4095518$

González, J. (2010). Re-imaginando y re-interpretando a las mujeres en la independencia: historiografía colombiana y género. Procesos Históricos, IX(17), 2-18. Recuperado de: http://www.saber.ula.ve/bitstream/123456789/30361/1/articulo1.pdf

Gutiérrez, D. (2014). Matar a un rey ausente. Los regicidios simbólicos durante el interregno neogranadino (1808-1816). Economía y Política, I(2), 5-37. DoI: 10.15691/07194714.2014.005

Gutiérrez, A. (2010). Simón Bolívar y la carta de Jamaica. Araucaria. Revista Iberoamericana de Filosofía, Política y Humanidades, 12(24), 251-270. Recuperado de: https:// ojs.publius.us.es/ojs/index.php/araucaria/article/view/1297/1191

König, H. (2009). Ciudadano, Colombia. En J. Fernández (dir.), Diccionario político y social del mundo iberoamericano. La era de las revoluciones, 1750-1850 (pp. 234-246). Madrid: Fundación Carolina/Sociedad Estatal de Conmemoraciones Culturales/ Centro de Estudios Políticos y Constitucionales.

Lomné (2009). América, Colombia. En J. Fernández (dir.), Diccionario político y social del mundo iberoamericano. La era de las revoluciones, 1750-1850 (pp. 101-115). Madrid: Fundación Carolina/Sociedad Estatal de Conmemoraciones Culturales/Centro de Estudios Políticos y Constitucionales.

López, G. (2006). Cultura jurídica e imaginario monárquico: las peticiones de indulto durante el segundo imperio mexicano. Historia Mexicana, 55(4), 1289-1351. Recuperado de http://www.redalyc.org/articulo.oa?id=60055406

Lux, M. (2011). Nuevas perspectivas de la categoría de género en la historia: de las márgenes al centro. Historia Crítica, 44, 128-156. DoI: http://dx.doi.org/10.7440/ histcrit44.2011.07

Lux, M. (2014). Mujeres patriotas y realistas entre dos órdenes. Discursos, estrategias y tácticas en la guerra, la política y el comercio (Nueva Granada, 1790-1830). Bogotá: Ediciones UniAndes.

Martínez Garnica, A. (2007a). La desigual conducta de las provincias neogranadinas en el proceso de la independencia. Anuario de Estudios Bolivarianos, XIII(14), 57-79. Recuperado de: http://bolivarium.usb.ve/pub/anuarios/Anuario\%20de\%20Estu dios\%20Bolivarianos_N-14_2007.pdf

\section{()(1) $\$$}


Martínez Garnica, A. (2007b). La reasunción de la soberanía por las juntas de notables en el Nuevo Reino de Granada. En M. Chust (coord.), 1808. La eclosión juntera en el mundo hispano (286-333). México: FCE.

Muñoz, L. (2011). Mujeres del sur en la independencia de la Nueva Granada. Pasto: Graficolor.

Murray, P. (2009). Mujeres, género y política en la joven república colombiana: una mirada desde la correspondencia personal del general Tomás Cipriano de Mosquera. Historia Crítica, 37, 54-71. Recuperado de: https://historiacritica.uniandes. edu.co/view.php/570/index.php?id=570

Orrego, J., Aljovín, C. y López, J. (2009). Introducción. En J. Orrego, C. Aljovín y J. López (comps.), Las independencias desde la perspectiva de los actores sociales (pp. 1116). Lima: Organización de Estados Iberoamericanos para la Educación, la Ciencia y la Cultura.

Owensby, B. (2011). Pacto entre rey lejano y súbditos indígenas. Justicia, legalidad y política en Nueva España, siglo xvir. Historia Mexicana, 61(1), 59-106. Recuperado de: http://historiamexicana.colmex.mx/index.php/RHM/article/view/279

Palti, E. (2007). El tiempo de la política: el siglo XIX reconsiderado. Buenos Aires: Siglo Veintiuno Editores.

Pani, E. (2006). "Ciudadana y muy ciudadana"? Women and the state in independent Mexico, 1810-1830. Gender and History, 18(1), 5-19. DoI: 10.1111/j.14680424.2006.00411.x

Pani, E. (2009). Ties unbound. Membership and community during the wars of independence. The thirteen North American colonies (1776-1783) and New Spain (1808-1821. En F. Morelli, C. Thibaud y G. Verdo (coords.), Les empires atlantiques. Des Lumières au libéralisme (1763-1865) (39-66). Rennes: Presses Universitaires de Rennes.

Páramo, C. (2010). Tribunal de purificación contra culpables y seducidos. En P. Rodríguez (coord.), Historia que no cesa. La independencia de Colombia 1780-1830 (8798). Bogotá: Editorial Universidad del Rosario.

Penagos, J. (2012). La prensa en la Nueva Granada entre 1810 y 1812. Folios, 27, 15-45. Recuperado de: http://aprendeenlinea.udea.edu.co/revistas/index.php/folios/ article/view/12764/11503

Phelan, J. L. (2009). El pueblo y el rey. La revolución comunera en Colombia, 1781. Bogotá: Editorial Universidad del Rosario.

Pulido, D. (2011). Policía: del buen gobierno a la seguridad, 1750-1850. Historia Mexicana, 60(3), 1195-1642. Recuperado de: http://www.jstor.org/stable/41151294

\section{(ㅇ)(1) $(3$}


Quintero, I. (2005). La criolla principal. María Antonio Bolivar, hermana del libertador. Caracas: Fundación Bigott.

Quintero, I. y Martínez, A. (eds.) (2007). Actas de formación de juntas y declaraciones de independencia (1809-1822) (t. II). Bucaramanga: Universidad Industrial de Santander.

Ramírez, M. H. (2010). Las vicisitudes de la vida de las mujeres durante la independencia de la Nueva Granada. En Otras Palabras, 18, 95-100. Recuperado de: https:// issuu.com/revistaenotraspalabras/docs/revista_en_otras_palabras_18

Ramírez, M. H. (2002). Las mujeres y la sociedad colonial de Santafé de Bogotá: 1750-1810. Bogotá: Instituto Colombiano de Antropología e Historia.

Ramírez, M. H. (2014). Las mujeres y la independencia de la Nueva Granada. Historiografía e iconografía. En J. D. Cortés, El bicentenario de la independencia. Legados y realizaciones a doscientos años (pp. 253-281). Bogotá: Universidad Nacional de Colombia.

Restrepo, I. (2005). La soberanía del "pueblo" durante la época de la independencia, 1810-1815. Historia Crítica, 29, 101-123. Recuperado de: https://historiacritica. uniandes.edu.co/view.php/297/index.php?id=297

Reyes, C. (2010). El derrumbe de la primera república en la Nueva Granada entre 1810 y 1816. Historia Crítica, 41, 36-61. DoI: http://dx.doi.org/10.7440/histcrit41.2010.05

Roseberry, W. (2002). Hegemonía y lenguaje contencioso. En J. Gilbert y D. Nugent (comps.), Aspectos cotidianos de la formación del Estado (pp. 213-226). México: Ediciones Era.

Santos Molano, E. (2010). Mujeres libertadoras, Las policarpas de la independencia. Bogotá: Planeta.

Scott, J. (1991). Historia de las mujeres. En P. Burke (ed.), Formas de hacer historia (pp. 59-88). Madrid: Alianza Editorial.

Scott, J. (2012). Género e historia. México: FCE.

Serrano, A. (2012). Mujeres y conciencia política en el proceso de independencia de la Nueva Granada. El caso de la ciudad de Santafé, 1810-1820. (Tesis de maestría inédita). Colmex, México.

Serrano, M. (2014). Orígenes de la formación de la ciudadanía en el Nuevo Reino de Granada. En J. D. Cortés, El bicentenario de la independencia. Legados y realizaciones a doscientos años (pp. 141-174). Bogotá: Universidad Nacional de Colombia.

Torres, C. (1960). Memorial de agravios de Camilo Torres. Boletín de la Sociedad Geográfica de Colombia, xviII(66-67), 1-23. Recuperado de: http://www.sogeocol.edu. co/documentos/067_mem_de_agrav.pdf

\section{()(1) $\$$}


Valencia, A. (2001). Mujeres caucanas y sociedad republicana. Santiago de Cali: Anzuelo Ético Editores.

Villegas, C. (2006) Del hogar a los juzgados: reclamos familiares ante la Real Audiencia de Santafé a finales del periodo colonial (1800-1809). Historia Crítica, 31, 101120. Recuperado de: https://historiacritica.uniandes.edu.co/view.php/272/index. php?id=272

\section{OTRAS FUENTES}

\section{Archivo}

AGN Archivo General de la Nación, Colombia.

\section{Bibliografía}

Almario, O. (2007). La desigual conducta de las provincias neogranadinas en el proceso de la independencia. Anuario de Estudios Bolivarianos, XIII(14), 57-79. Recuperado de http://bolivarium.usb.ve/pub/anuarios/Anuario\%20de\%20Estudios\%20 Bolivarianos_N-14_2007.pdf

Cunill, C. (2011). El indio miserable: nacimiento de la teoría legal en la América colonial del siglo xvi. Cuadernos inter.c.a.mbio, 8(9), 229-248. Recuperado de: http:// revistas.ucr.ac.cr/index.php/intercambio/article/view/2223/2184

Escobeda, R. (1995). El bando de buen gobierno, instrumento de la ilustración. En Memorias del X Congreso del Instituto Internacional de Historia del Derecho Indiano (t. I, pp. 473-496). México: Escuela Libre de Derecho/Universidad Nacional Autónoma de México. 